ORNL/TM-2015/595

\title{
Development and Mechanical Results of Zr-Bearing Ferritic Steels
}

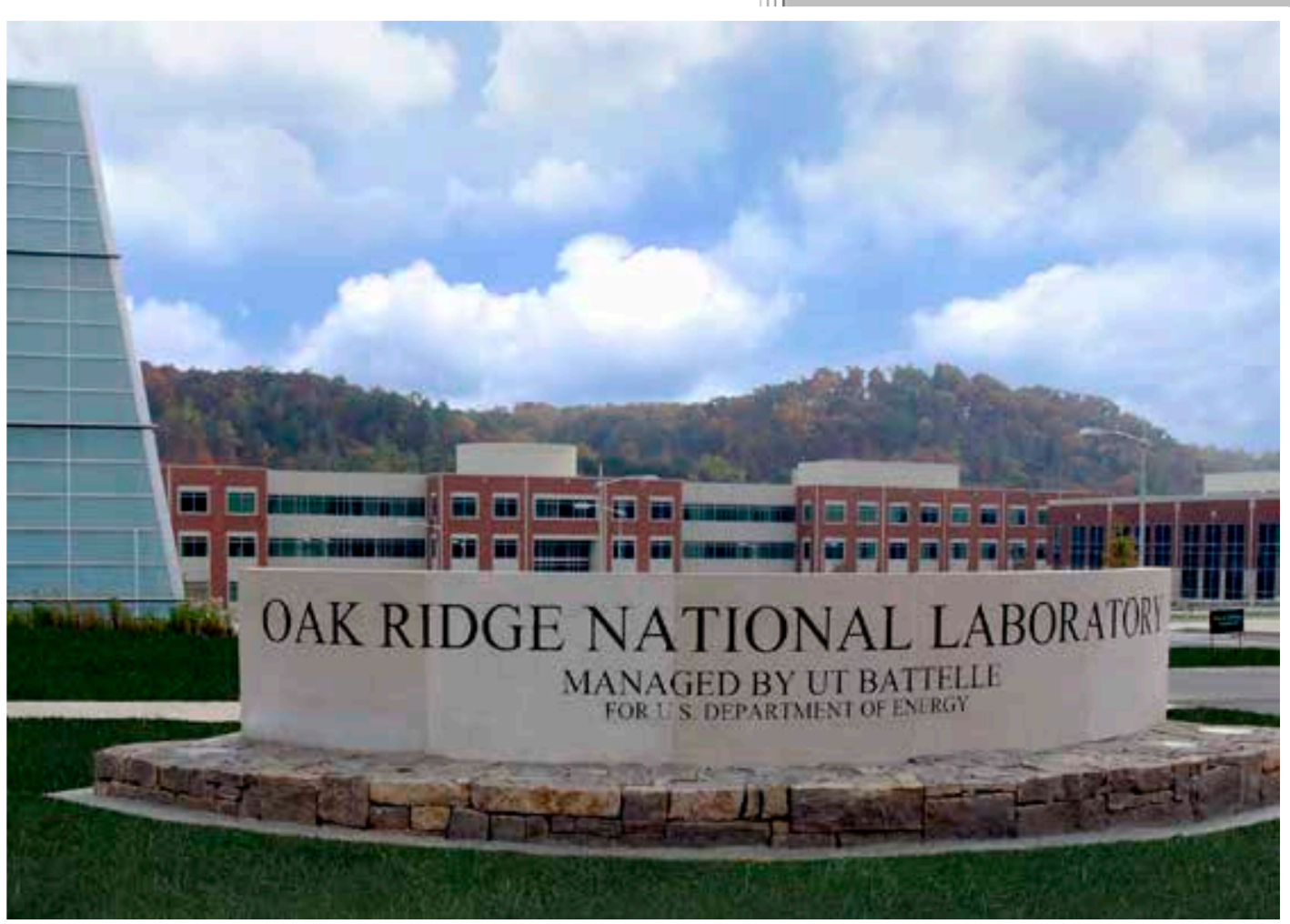

Lizhen Tan

Oak Ridge National Laboratory

October 2015 


\section{DOCUMENT AVAILABILITY}

Reports produced after January 1, 1996, are generally available free via US Department of Energy (DOE) SciTech Connect.

Website http://www.osti.gov/scitech/

Reports produced before January 1, 1996, may be purchased by members of the public from the following source:

National Technical Information Service

5285 Port Royal Road

Springfield, VA 22161

Telephone 703-605-6000 (1-800-553-6847)

TDD 703-487-4639

Fax 703-605-6900

E-mail info@ntis.gov

Website http://www.ntis.gov/help/ordermethods.aspx

Reports are available to DOE employees, DOE contractors, Energy Technology Data Exchange representatives, and International Nuclear Information System representatives from the following source:

Office of Scientific and Technical Information

PO Box 62

Oak Ridge, TN 37831

Telephone 865-576-8401

Fax 865-576-5728

E-mail reports@osti.gov

Website http://www.osti.gov/contact.html

This report was prepared as an account of work sponsored by an agency of the United States Government. Neither the United States Government nor any agency thereof, nor any of their employees, makes any warranty, express or implied, or assumes any legal liability or responsibility for the accuracy, completeness, or usefulness of any information, apparatus, product, or process disclosed, or represents that its use would not infringe privately owned rights. Reference herein to any specific commercial product, process, or service by trade name, trademark, manufacturer, or otherwise, does not necessarily constitute or imply its endorsement, recommendation, or favoring by the United States Government or any agency thereof. The views and opinions of authors expressed herein do not necessarily state or reflect those of the United States Government or any agency thereof. 
Nuclear Energy Enabling Technologies (NEET) FY 2012 Award

M2CT-12-TN-OR0402025

\title{
DEVELOPMENT AND MECHANICAL RESULTS OF ZR-BEARING FERRITIC
} STEELS

\author{
Lizhen Tan \\ Oak Ridge National Laboratory
}

Date Published: October 2015

Prepared by

OAK RIDGE NATIONAL LABORATORY

Oak Ridge, Tennessee 37831-6283

managed by

UT-BATTELLE, LLC

for the

US DEPARTMENT OF ENERGY

under contract DE-AC05-00OR22725 



\section{CONTENTS}

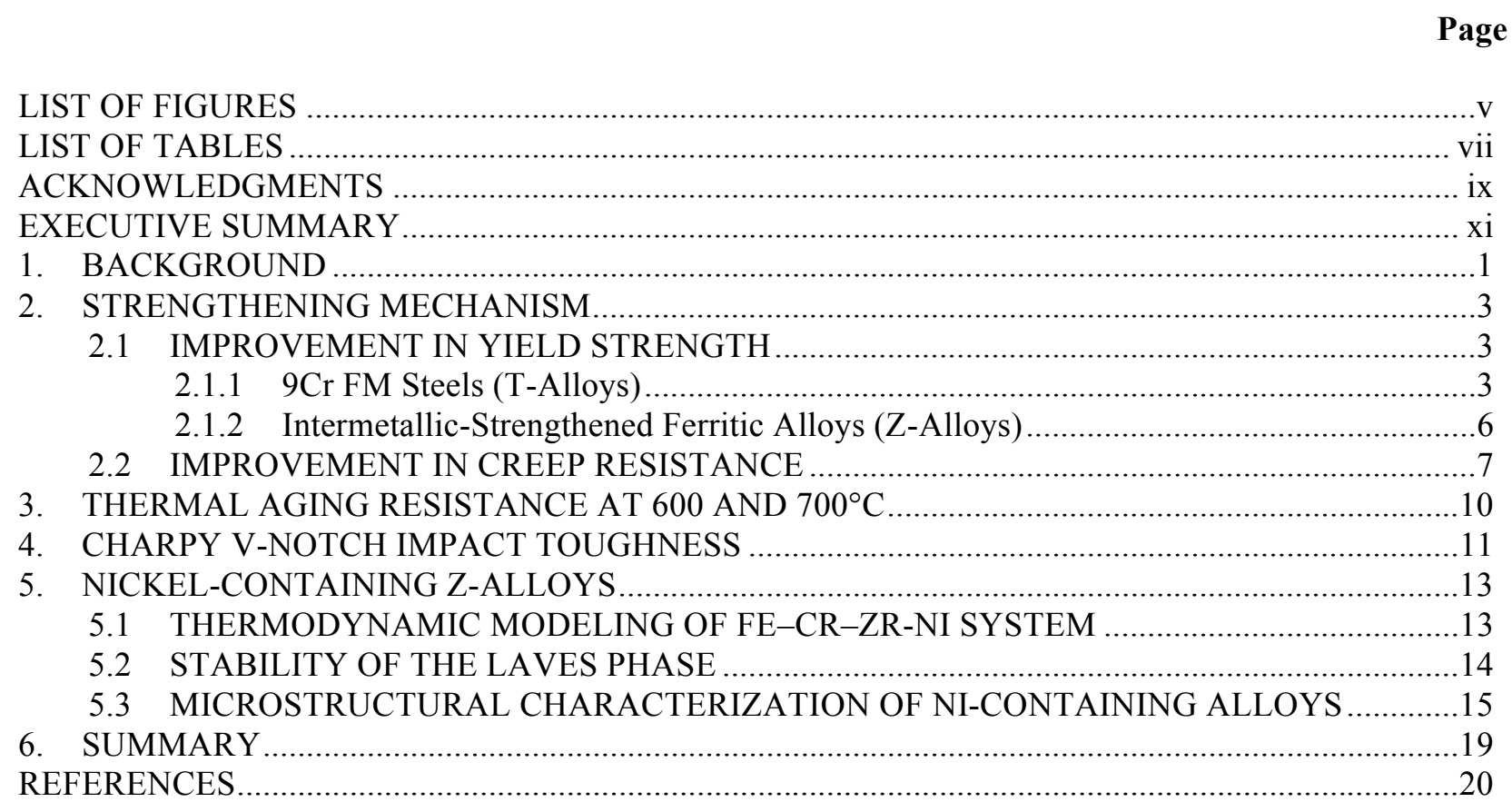





\section{LIST OF FIGURES}

Figure $\quad$ Page

Figure 1. Specification of type SS-3 specimen (unit: inch) …..............................................................

Figure 2. Temperature-dependent yield strength and total elongation of $\mathrm{T}$-alloy as compared with

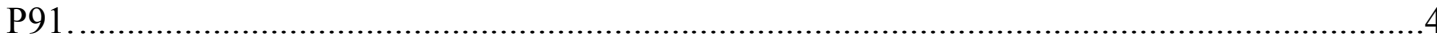

Figure 3. BF image of a T-alloy as compared with P91 . ..................................................................

Figure 4. Temperature-dependent yield strength and total elongation of Z-alloys as compared with

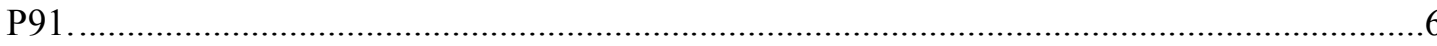

Figure 5. Optical micrographs of Z-alloys (Z7 and Z9) showing eutectic network confined ferritic

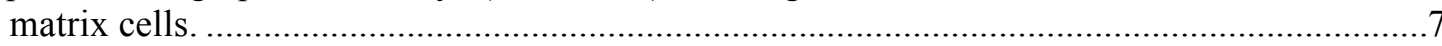

Figure 6. Creep curves of T-alloy and Z-alloy as compared with the data of $\mathrm{P} / \mathrm{T} 91$ at $650^{\circ} \mathrm{C}$ and $110 \mathrm{MPa}$.

Figure 7. Microstructural comparison between the gauge and tab sections of a creep ruptured T-alloy at $650^{\circ} \mathrm{C}$ and $110 \mathrm{MPa}$.

Figure 8. Microstructure of the gauge section of a creep ruptured $\mathrm{Z}$-alloy at $650^{\circ} \mathrm{C}$ and $110 \mathrm{MPa} \ldots \ldots \ldots \ldots . . .9$

Figure 9. Changes of yield strength (YS), tensile strength (TS), and total elongation (EL) at room temperature of the T-alloys and Z-alloys after aging at 600 and $700^{\circ} \mathrm{C}$ for 5,906 and $5,236 \mathrm{~h}$, respectively.

Figure 10. Specification of half-size Charpy V-notch specimen.

Figure 11. Charpy V-notch impact tested data and fitted curves of T-alloys in the T-L orientation as compared with Grade 91.

Figure 12. Partial isothermal section of $\mathrm{Fe}-\mathrm{Ni}-\mathrm{Zr}$ at $1,000^{\circ} \mathrm{C}$ : (a) experimental, (b) calculated. .13

Figure 13. The mole fraction of the $\mathrm{C} 14$ and $\mathrm{C} 15$ Laves phase vs. temperature in the Fe- $12 \mathrm{Cr}-6 \mathrm{Zr}$ base alloy with different additions of $\mathrm{Ni}$. The solid, dashed and dotted lines denote 0.5 , 2 and $4 \mathrm{wt} \% \mathrm{Ni}$, respectively. The black and red colors denote the $\mathrm{C} 14$ and $\mathrm{C} 15$ structure, respectively.

Figure 14. The dissolved $\mathrm{Ni}$ in the $\mathrm{C} 14$ and $\mathrm{C} 15$ Laves phase vs. temperature in the $\mathrm{Fe}-12 \mathrm{Cr}-6 \mathrm{Zr}$ base alloy with different additions of $\mathrm{Ni}$. The solid, dashed and dotted lines denote 0.5 , 2 and $4 \mathrm{wt} \% \mathrm{Ni}$, respectively. The black and red colors denote the C14 and C15 structure, respectively.....

Figure 15. BEIs of Fe-12Cr-6Zr base alloy with additions of (a) 0.5 and (b) $4 \mathrm{wt} \% \mathrm{Ni}$........................16

Figure 16. EBSD IQ and IPF maps of Fe-12Cr-6Zr alloys with $(\mathrm{a}-\mathrm{b}) 0.5$ and $(\mathrm{c}-\mathrm{d}) 4 \mathrm{wt} \% \mathrm{Ni} . \ldots \ldots \ldots \ldots . . . .17$

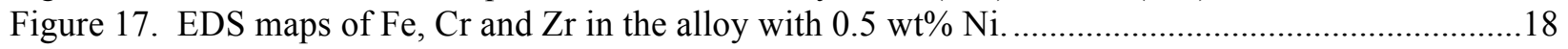

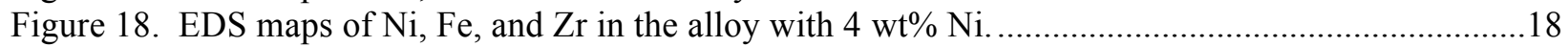




\section{LIST OF TABLES}

\section{Table}

Page

Table 1. Comparison of strengthening elements (MX precipitates and free dislocations) in T-alloy and P91.

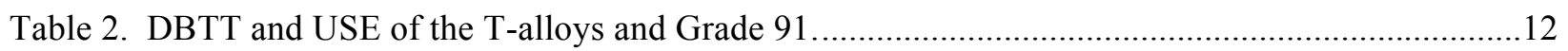





\section{ACKNOWLEDGMENTS}

This research was sponsored by the U.S. Department of Energy (DOE), Office of Nuclear Energy (NE), the Nuclear Energy Enabling Technologies (NEET) FY 2012 Award. This research was supported in part by the Office of Nuclear Energy, Science and Technology and by the Center for Nanophase Materials Sciences (CNMS), which is sponsored by the Scientific User Facilities Division, Office of Basic Energy Sciences, U.S. Department of Energy. We gratefully acknowledge the support provided by Sue Lesica of DOE-NE and Jeremy Busby of Oak Ridge National Laboratory (ORNL).

The authors are grateful to Ying Yang of ORNL for her support on the thermodynamic modeling and to Eric Manneschmidt, Tom Geer, David Harper, Greg Cox, and Zhenggang Wu of ORNL for their technical support throughout the project. 



\section{EXECUTIVE SUMMARY}

The mission of the Nuclear Energy Enabling Technologies (NEET) program is to develop crosscutting technologies for nuclear energy applications. Advanced structural materials with superior performance at elevated temperatures are always desired for nuclear reactors, which can improve reactor economics, safety margins, and design flexibility. They benefit not only new reactors, including advanced light water reactors (LWRs) and fast reactors such as the sodium-cooled fast reactor (SFR) that is primarily designed for management of high-level wastes, but also life extension of the existing fleet when component exchange is needed. Developing and utilizing the modern materials science tools (experimental, theoretical, and computational tools) is an important path to more efficient alloy development and process optimization.

Ferritic-martensitic (FM) steels are important structural materials for nuclear reactors due to their advantages over other applicable materials such as austenitic stainless steels, notably their resistance to void swelling, low thermal expansion coefficients, and higher thermal conductivity. However, traditional FM steels exhibit a noticeable yield strength reduction at elevated temperatures above $\sim 500^{\circ} \mathrm{C}$, which limits their applications in advanced nuclear reactors which target operating temperatures above this temperature. Although oxide-dispersion-strengthened (ODS) ferritic steels have shown excellent hightemperature performance, their extremely high cost, limited size and fabricability of products, as well as the great difficulty with welding and joining, have limited or precluded their large-scale commercial applications. Zirconium has shown many benefits to Fe-based alloys such as grain refinement, improved phase stability, and reduced radiation-induced segregation. The ultimate goal of this project is, with the aid of computational modeling tools, to accelerate the development of Zr-bearing ferritic alloys that can be fabricated using conventional steelmaking methods. The new alloys are expected to have superior high-temperature creep performance and excellent radiation resistance as compared to Grade 91.

Using the developed thermodynamic database, three series of ferritic alloys have been developed. They are T-alloys (9Cr FM steels), Z-alloys (intermetallic-strengthened ferritic alloys), and L-alloys (15Cr ferritic steels). Unlike 9Cr FM steels such as T-alloys and P91, the Z-and L-alloys are fully ferritic alloys, without the ferrite-austenite phase transformation during heating and cooling, leading to easier alloy fabrication and superior high-temperature strength. Development of L-alloys was discontinued in the second year of this project because of their mediocre strength and significant radiation hardening as compared to P91.

The continued development and investigation of the T-alloys and Z-alloys in the third year of this project identified the strengthening mechanisms for the superior yield/tensile strength and creep resistance as compared to P91. The T-alloys exhibited $\sim 300$ to $100 \mathrm{MPa}$ increases in yield/tensile strength from room temperature to $\sim 750^{\circ} \mathrm{C}$. The Z-alloys showed comparable or slightly lower yield strength at temperatures below $\sim 600^{\circ} \mathrm{C}$, above which the Z-alloys exhibited higher yield strength approaching the T-alloys. Microstructural characterization and the modeling of strengthening elements suggest that the notable strength increase of the T-alloys is primarily attributable to the significantly increased amount of ultrafine $\mathrm{MX}(\mathrm{M}=$ metal, $\mathrm{X}=\mathrm{C} / \mathrm{N})$ type nanoprecipitates. In contrast, the $\mathrm{Z}$-alloys are primarily strengthened by the network of eutectic structure. The T-alloys and Z-alloys had increased creep lives by 2 to 4 times the $\mathrm{P} 91$ tested at $650^{\circ} \mathrm{C}$ and $110 \mathrm{MPa}$. The increased amount of MX nanoprecipitates in the T-alloys helped pin the subgrains during creep. Many ultrafine particles $(\sim 10 \mathrm{~nm})$ were randomly formed in the Z-alloys during the creep test, which helped improve creep life without impairing creep ductility. Thermal aging at 600 and $700^{\circ} \mathrm{C}$ for more than $5,200 \mathrm{~h}$ indicated that a small amount of $\mathrm{Zr}$ alloying can mitigate aging-induced softening in the T-alloys. In contrast, the Z-alloys exhibited some aging-induced hardening without noticeable changes to total elongation, which is attributable to new phase precipitation similar to that formed during the creep test. Charpy V-notch impact tests showed the significant 
improvement in impact toughness of the T-alloys as compared to P91, e.g., $\sim 20^{\circ} \mathrm{C}$ decrease in ductilebrittle transition temperature and about double the upper-shelf energy of P91. However, the impact toughness of the Z-alloys was significantly lower, which needs to be further investigated and developed. Thermodynamic modeling indicates that nickel alloying into the Z-alloys can favor Laves phase formation in cubic $\mathrm{C} 15$ structure rather than the hexagonal C14 structure. The C15 type Laves is believed to have better fracture toughness as well as coherency with ferritic phase as compared to the C14 type. Preliminary experimental Z-alloys with 0.5 to $4 \mathrm{wt} \% \mathrm{Ni}$ confirmed the significant participation of $\mathrm{Ni}$ in the $\mathrm{Fe}_{2} \mathrm{Zr}$ Laves phase of the alloy with $4 \mathrm{wt} \% \mathrm{Ni}$. Preliminary electron backscattered electron mapping suggested the presence of some C15 type Laves phase. Detailed microstructural analysis will confirm the formation of the $\mathrm{C} 15$ type $\mathrm{Fe}_{2} \mathrm{Zr}$ Laves phase with Ni participation. 


\section{BACKGROUND}

Nuclear power currently provides a significant fraction of the United States' non-carbon emitting electric power generation. In future years, nuclear power must continue to generate a significant portion of the nation's electricity to meet the growing power demand, carbon-free energy goals, and to ensure energy independence. New reactors will be an essential part of the expansion of nuclear power. However, given limits on new builds imposed by economics and industrial capacity, the extended service of the existing nuclear fleet will also be required. Advanced structural materials with superior performance at elevated temperatures are always desired for nuclear reactors because they can improve reactor economics, safety margins, and design flexibility. They benefit not only new reactors including advanced light water reactors (LWRs) and fast reactors such as sodium-cooled fast reactors (SFRs) primarily designed for management of high-level wastes, but these new materials also improve life extension of the existing fleet when component exchange is needed.

Ferritic-martensitic (FM) steels are an important category of structural materials because of their outstanding resistance to radiation-induced void swelling (e.g., $\sim 1$ vol.\% per 100 displacements-per-atom (dpa) in FM steels versus $\sim 1$ vol.\% per 10 dpa in austenitic stainless steels at temperatures above $300^{\circ} \mathrm{C}$ [1]), high thermal conductivity, and low thermal expansion coefficients compared to austenitic stainless steels [2]. The body-centered cubic (bcc) structure of ferrite provides the inherent resistance to void swelling compared to the face-centered cubic (fcc) structure of austenitic alloys [3]. The formation of martensite followed by the tempering treatment introduces a large amount of lath boundaries and dislocations into the ferrite matrix, leading to refined precipitates and increased strength with decent fracture toughness [4]. However, the dislocations and lath boundaries are not stable at elevated temperatures, resulting in softening due to the impaired pinning effect induced by the instability of precipitates $[4,5]$. Zirconium (Zr) has shown many benefits to Fe-based alloys, such as introduced ultrafine new phases, improved coarsening resistance of Zr-bearing phases [6], and reduced radiationinduced segregation (RIS) [7,8]. Thus, it is expected that $\mathrm{Zr}$ has a beneficial role in improving hightemperature performance. This project's goal is to develop Zr-bearing ferritic alloys aided by computational alloy thermodynamics.

In contrast to traditional experimental trial-error methods, computational alloy thermodynamics (a scientific approach to systematically study the relationship between thermodynamic properties and phase stability) provides effective and economic practices for alloy development. The primary microstructures of new alloys can be simulated on a desktop computer within a short period of time, which guides the design of new alloys for experimental verification and performance examination. To facilitate the development of Zr-bearing ferritic steels, a thermodynamic database of Fe-C-Cr-Mo-Nb-Ti-W-Zr had been developed in Year 1 of this project. The computational thermodynamics tool helped the design of Zr-bearing ferritic steels in three series: (I) 9Cr FM (named T-alloys), (II) intermetallic-strengthened ferritic alloys (named Z-alloys), and (III) high-Cr (> 12Cr) ferritic steels (named L-alloys).

During the course of alloy development and testing activities in the first two years of this project, the composition of T-alloys has been refined as $0.08-0.12 \mathrm{C}, 8.3-8.8 \mathrm{Cr},<1.0 \mathrm{Mn}, 0.10-0.25 \mathrm{~V}, 1.0-1.5 \mathrm{~W}$, $<0.15 \mathrm{Ni},<0.2 \mathrm{Si},<0.10 \mathrm{Nb} / \mathrm{Ta},<0.15 \mathrm{Ti},<0.06 \mathrm{Zr}$; Z-alloys as $8-12 \mathrm{Cr}, 3-8 \mathrm{Zr}, 1-2 \mathrm{~W},<0.5 \mathrm{Mo}$, $<1.0 \mathrm{Mn},<0.5 \mathrm{Si}$; and L-alloys as $<0.02 \mathrm{C}, 15 \mathrm{Cr}, 1-3 \mathrm{~W},<1 \mathrm{Mo},<0.4 \mathrm{Nb},<0.5 \mathrm{Mn},<0.2 \mathrm{Si}$, and $<0.06 \mathrm{Zr}$ with $\mathrm{Fe}$ as balance. Development and investigation of L-alloys were discontinued in the second year of this project because of their mediocre mechanical properties as compared to Grade 91 and their significant hardening after proton irradiation to $\sim 1 \mathrm{dpa}$ at $420^{\circ} \mathrm{C}[9,10]$. T-alloys and Z-alloys exhibited strength superior or comparable to Grade 91. Under the same proton irradiation as the L-alloys, T-alloys showed slightly lower hardening than Grade 91 . In contrast, Z-alloys showed a large variation in hardening, suggesting noticeable alloy composition effect. 
This report describes the continued development and testing results of T-alloys and Z-alloys in the third year of this project. It describes the strengthening mechanism, thermal aging resistance, Charpy V-notch impact toughness, and effect of nickel on Z-alloys. 


\section{STRENGTHENING MECHANISM}

\subsection{IMPROVEMENT IN YIELD STRENGTH}

Type SS-3 miniature specimens were used to screen tensile properties of the designed alloys due to their limited heat size. The specification of this type of specimens is shown in Figure 1. The specimens were machined from the heats with specimen length parallel to the longitudinal direction of the heats. Tensile testing was conducted on the specimens at temperatures from ambient temperature up to $800^{\circ} \mathrm{C}$ in accordance with the American Society for Testing and Materials (ASTM) standard E8/E8M-13a, Standard Test Methods for Tension Testing of Metallic Materials, and E21/E21M-09, Standard Test Methods for Elevated Temperature Tension Tests of Metallic Materials. Tests were performed using an MTS tensile testing system with a load cell possessing $22 \mathrm{kN}(5,000 \mathrm{lbf})$ capacity, which is integrated in the load train and placed in the water-cooled zone below the hot zone of the furnace. Due to the small specimen size, an extensometer was not used during the tests. Tensile testing was performed at a crosshead speed of $0.0076 \mathrm{~mm} / \mathrm{s}(0.018 \mathrm{in} . / \mathrm{min})$, corresponding to a nominal strain rate of $0.001 \mathrm{~s}^{-1}$. The tensile testing system, load cells, and furnace thermocouples were regularly calibrated.

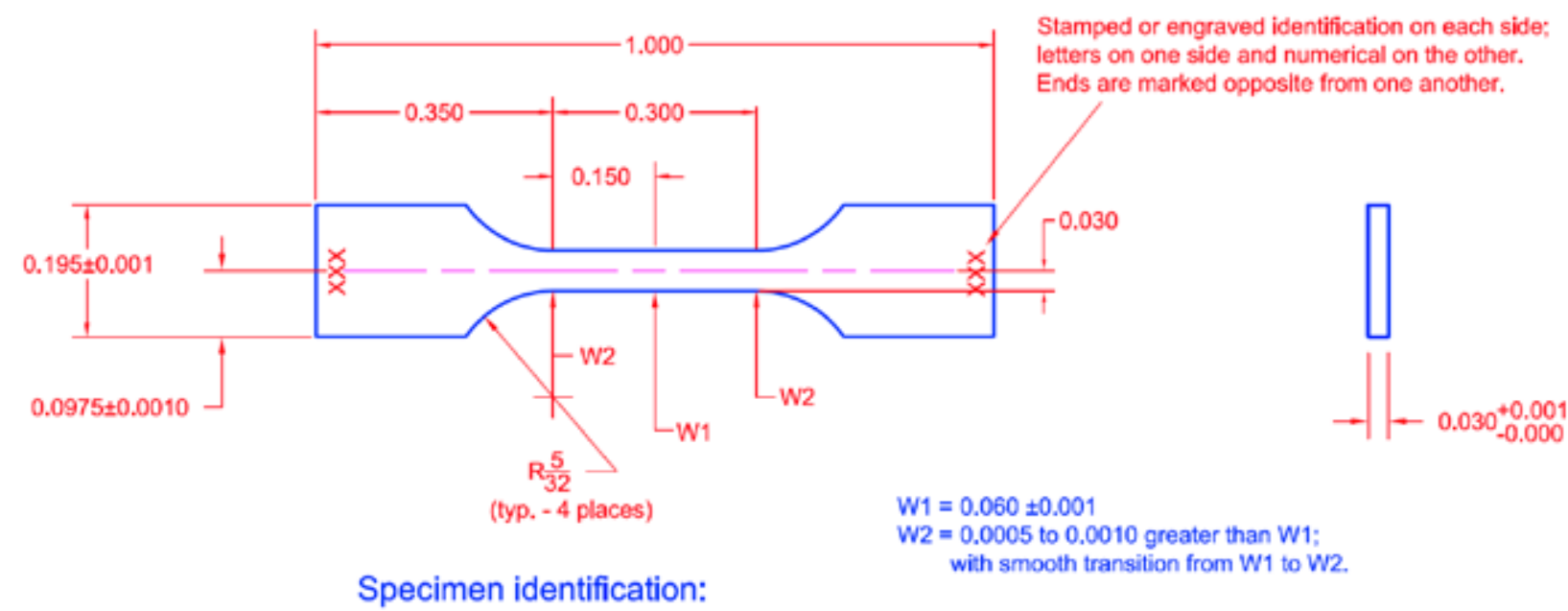

Notes:

1. Tolerances:

$X . X X= \pm 0.01$

$X \times X X X= \pm 0.005$

2. All machined surfaces, 32 finish or better.

3. No burrs. Keep sharp edges on entire specimen.

\section{SS-3 Tensile Specimen}

Drawing \#: NMST-092905

Drawn by: Eric Manneschmidt

Figure 1. Specification of type SS-3 specimen (unit: inch).

\subsubsection{Cr FM Steels (T-Alloys)}

Additional T-alloys were developed by adjusting the content of $\mathrm{Ti} / \mathrm{Ta}$ and $\mathrm{Mn}$ in the third year of this project. Figure 2 shows the tensile test results of temperature-dependent yield strength and total elongation of T-alloys as compared to P91 from the National Institute for Materials Science (NIMS) Creep Data Sheet No. 43. In general, the six T-alloys exhibited similar yield strength that is higher than P91, e.g., up to $\sim 300 \mathrm{MPa}$ higher at room temperature and up to $\sim 100 \mathrm{MPa}$ higher at $700^{\circ} \mathrm{C}$. Similar to other general alloys, the increased strength was compensated by some reduction in total elongation. Considering the miniature size of type SS-3 specimens, which has a gauge cross-sectional area about 1/68 
of the P91 as schematically shown in the inset of Figure 2, the total elongations at room temperature of the T-alloys comply with the minimum requirement of $10.96 \%(=32 t+10.00$, where $t=0.03$ in. $)$ according to the ASTM standard A335/A335M-11, "Standard specification for seamless ferritic alloy-steel pipe for high-temperature service."
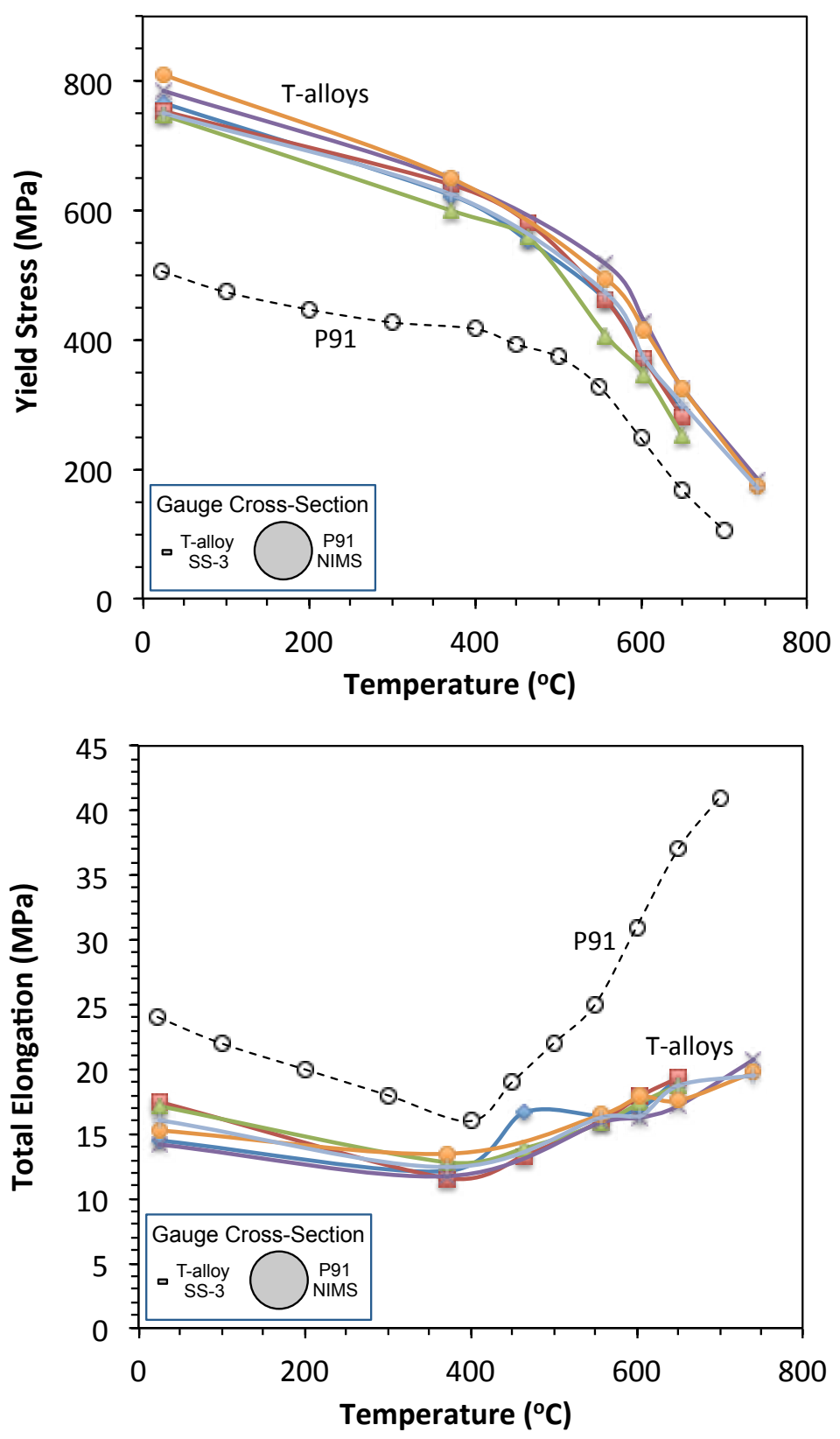

Figure 2. Temperature-dependent yield strength and total elongation of T-alloy as compared with P91.

Microstructural characterization using transmission electron microscopy (TEM) was conducted on some of the T-alloys. Figure 3 shows an example of a T-alloy in bright-field (BF) image. In addition to the few large particles $(\sim 50-100 \mathrm{~nm})$ decorating the prior-austenite grain boundary at the lower left corner, a high density of ultrafine precipitates $(<10 \mathrm{~nm})$ dispersed in the matrix together with many free dislocations. In contrast, only a few precipitates $(\sim 20-100 \mathrm{~nm})$ are distributed in the matrix. 

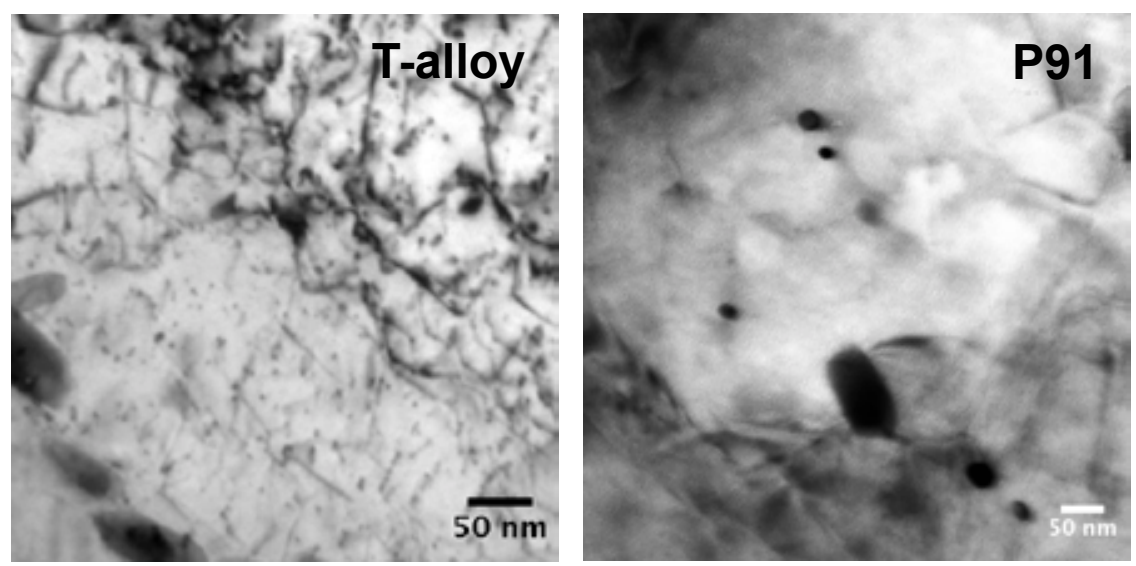

Figure 3. BF image of a T-alloy as compared with P91.

In general, there are three types of primary strengthening elements in FM steels, such as subgrain (lath) boundaries, precipitates, and free dislocations. The contribution of subgrain boundaries to strength can be estimated by $\sigma_{\mathrm{sgb}}=k G b / \lambda_{\mathrm{sgb}}$, where $k$ is a constant $(\approx 10), G$ is the shear modulus $(\approx 86 \mathrm{GPa}), b$ is the Burgers vector $(\approx 0.25 \mathrm{~nm})$, and $\lambda_{\text {sgb }}$ is the width of the lath boundaries. Precipitate strengthening is often estimated by the dispersed barrier model following Orowan mechanism as $\sigma_{\mathrm{ppt}}=\alpha M G b(N d)^{1 / 2}$, where $\alpha$ is the strength factor calculable according to Ref. [11], $M$ is Taylor factor $(\approx 2.9$ for body centered cubic), and $N$ and $d$ are the volume number density and diameter of the precipitates, respectively. Free dislocation strengthening can be estimated by $\sigma_{\text {disl }}=0.5 M G b\left(\rho_{\text {disl }}\right)^{1 / 2}$, where $\rho_{\text {disl }}$ is the density of free dislocations. The characterized size and density of the MX precipitates and the density of free dislocations and subgrain boundaries are listed in Table 1. The resultant strength from the three strengthening elements, estimated according to the respective equations, is also included for both a typical T-alloy and P91 in Table 1. The calculation suggests $768 \mathrm{MPa}$ and $521 \mathrm{MPa}$ for the T-alloy and P91 at room temperature, which are approximately consistent with the tensile tested results as shown in Figure 2. The three strengthening elements exhibited different levels of increase in strength of the T-alloy as compared to P91. Subgrain boundaries have the highest contribution to strength in both of the steels. The notable strength increase of the T-alloy is primarily attributable to the significantly increased amount of ultrafine MX nanoprecipitates.

Table 1. Comparison of strengthening elements (MX precipitates and free dislocations) in T-alloy and P91.

\begin{tabular}{|c|c|c|c|}
\hline Size of $\mathrm{MX}(r, \mathrm{~nm})$ & $\sim 5$ & $\sim 20$ & $\sim 0.3$ times \\
\hline Density of MX $\left(N, \mathrm{~m}^{-3}\right)$ & Close to $10^{23}$ & $10^{21}$ & $\sim 50$ times \\
\hline Density of dislocations $\left(\rho_{\text {disl }}, \mathrm{m}^{-2}\right)$ & $10^{14}$ & Close to $10^{14}$ & $\sim 5$ times \\
\hline Subgrain boundaries $\left(\lambda_{\mathrm{sgb}}, \mathrm{nm}\right)$ & 400 & 500 & $\sim 0.7$ times \\
\hline Dislocation strengthening: $\sigma_{\text {disl }}(\mathrm{MPa})$ & 312 & 220 & 92 \\
\hline Precipitate strengthening: $\sigma_{\mathrm{MX}}(\mathrm{MPa})$ & 451 & 195 & 256 \\
\hline Subgrain boundary strengthening: $\sigma_{\mathrm{sgb}}(\mathrm{MPa})$ & 538 & 430 & 108 \\
\hline Overall strength: $\sqrt{\sigma_{M X}^{2}+\sigma_{\text {disl }}^{2}+\sigma_{\text {sgb }}^{2}}(\mathrm{MPa})$ & 768 & 521 & 247 \\
\hline
\end{tabular}




\subsubsection{Intermetallic-Strengthened Ferritic Alloys (Z-Alloys)}

Similar to Figure 2, the temperature-dependent yield strength and total elongation of the developed Z-alloys as compared with P91 are shown in Figure 4. As compared with P91, the Z-alloys generally have comparable or slightly lower yield strength at temperatures below $\sim 600^{\circ} \mathrm{C}$, above which the Z-alloys exhibited higher yield strength approaching the yield strength of T-alloys in Figure 2. In general, the Z-alloys exhibited total elongation comparable to the T-alloys at temperatures below $\sim 400^{\circ} \mathrm{C}$, above which the Z-alloys had superior total elongation approaching P91.
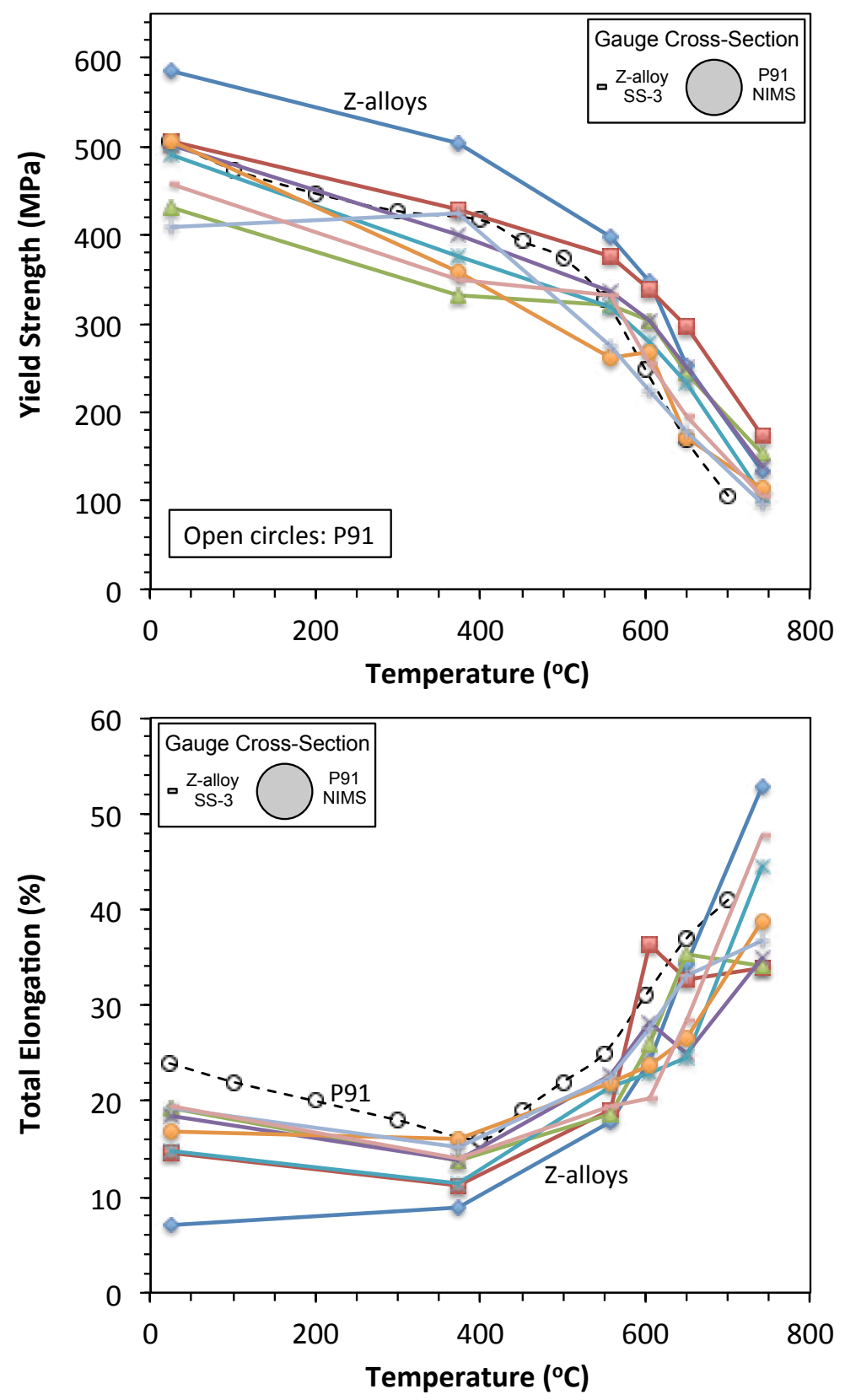

Figure 4. Temperature-dependent yield strength and total elongation of Z-alloys as compared with P91. 
The Z-alloys are primarily strengthened by the network of eutectic structure as shown in Figure 5 . The eutectic structure is composed of Zr-bearing Laves phase in white and ferrite phase in grey. The ferrite matrix is confined as cells by the eutectic network.
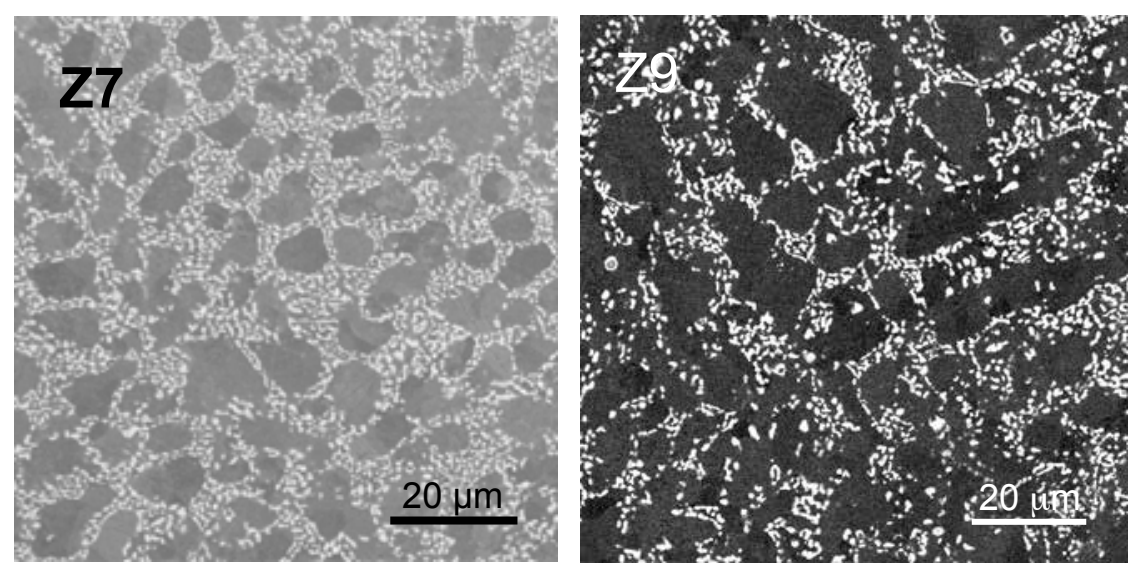

Figure 5. Optical micrographs of Z-alloys (Z7 and Z9) showing eutectic network confined ferritic matrix cells.

\subsection{IMPROVEMENT IN CREEP RESISTANCE}

Creep tests were conducted using the type SS-3 specimens at 550,600, and $650^{\circ} \mathrm{C}$. Figure 6 shows typical creep curves of a T-alloy and a Z-alloy tested at $650^{\circ} \mathrm{C}$ and $110 \mathrm{MPa}$. The data of P/T91 tested at the same condition are extracted from the NIMS Creep Data Sheet No. 43 and included in Figure 6.

Noticeable improvement in creep life was observed for the T-alloys and Z-alloys as compared to P/T91. In general, Z-alloys had longer creep life than T-alloys, as well as higher creep strain comparable to P/T91. Similar to the tensile tests, the miniature type SS-3 specimen is expected to have constrained creep strain as compared to the $\mathrm{P} / \mathrm{T} 91$ because of the significantly smaller gauge cross-section area of type SS-3 specimen that is about 1/68 of the gauge cross-section area of the P/T91 specimen. 


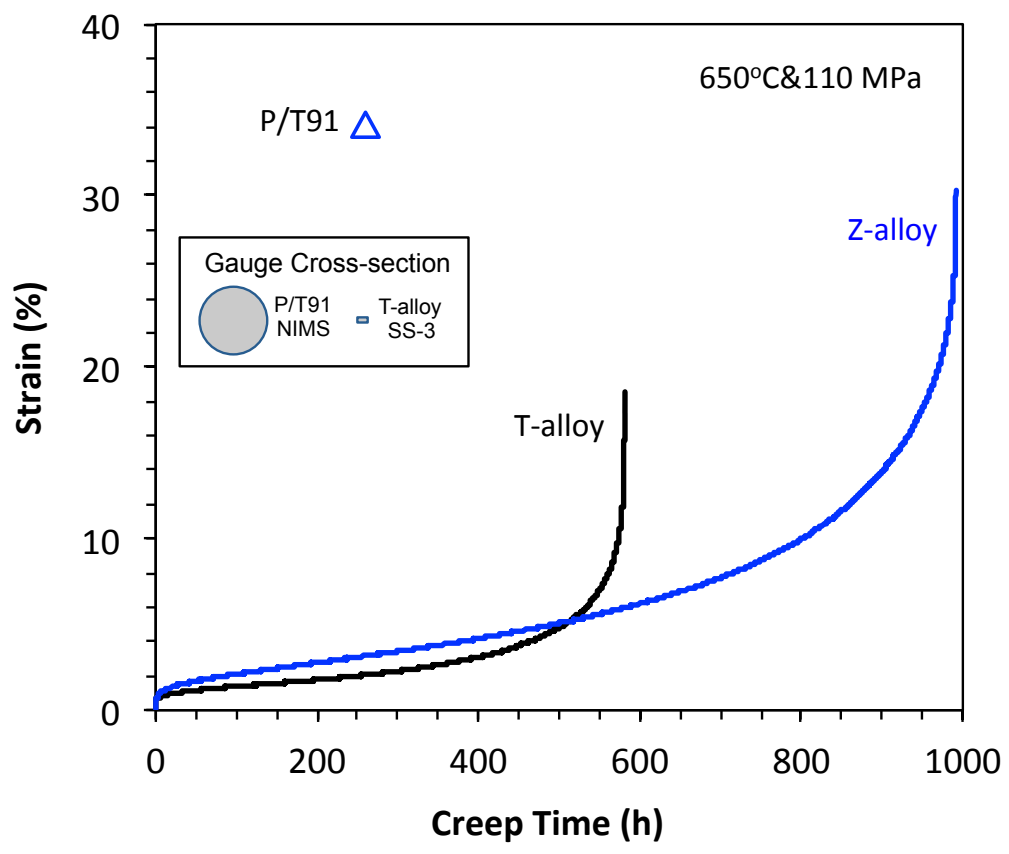

Figure 6. Creep curves of T-alloy and Z-alloy as compared with the data of P/T91 at $650^{\circ} \mathrm{C}$ and $110 \mathrm{MPa}$.

Figure 7 shows the TEM images of the creep-ruptured T-alloy at $650^{\circ} \mathrm{C}$ and $110 \mathrm{MPa}$ at the tab and gauge sections in both BF and dark-field (DF) modes. The tab section, under negligible stress during the creep test, shows a narrow lath without noticeable recovery. Many nanoprecipitates exist in the matrix with some viewable particles pinning the right lath boundary. In contrast, the gauge section, under significant stress during the creep test, shows some recovery, e.g., $\sim 500 \mathrm{~nm}$ subgrains in the BF image of the gauge section. A large amount of dislocation line approximately perpendicular to $g_{200}$ formed in the subgrains. The DF image of the gauge section shows some nanoprecipitates in white but many nanoprecipitates in grey that are deviated from the diffraction condition. The nanoprecipitates at the gauge section have size and density comparable to those at the tab section. The observation indicates that subgrain recovery is still the primary softening mechanism of the T-alloys, which is similar to conventional FM steels. The greater creep life of T-alloys as compared to P/T91 suggests that the T-alloys have smaller recovery levels than P/T91. Detailed microstructural analysis is still needed to help understand the mechanism of the improved creep life of the T-alloys.
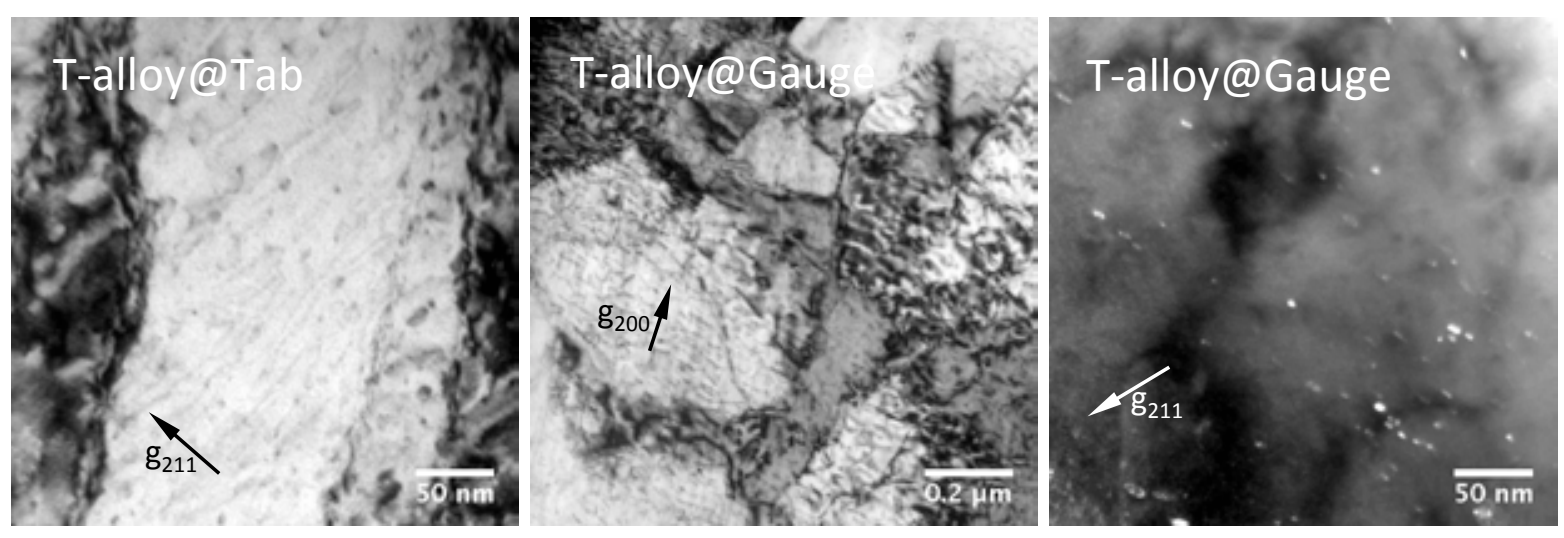

Figure 7. Microstructural comparison between the gauge and tab sections of a creep ruptured T-alloy at $650^{\circ} \mathrm{C}$ and $110 \mathrm{MPa}$. 
Figure 8 shows the $\mathrm{BF}$ image at the gauge section of the creep-ruptured Z-alloy tested at $650^{\circ} \mathrm{C}$ and $110 \mathrm{MPa}$. Many ultrafine particles with size about $10 \mathrm{~nm}$ are shown in the BF image with randomly orientated lattice fringes. The selected area diffraction pattern captured from this area shows a ring pattern of the particles on a [111] ferritic single grain matrix, which confirms the random orientation of the ultrafine particles. The ultrafine particles were formed during the creep test, which strengthened the alloy and extended its creep life. In the meantime, it seems that the dynamic precipitation of the ultrafine particles during the creep test did not impair creep strain.
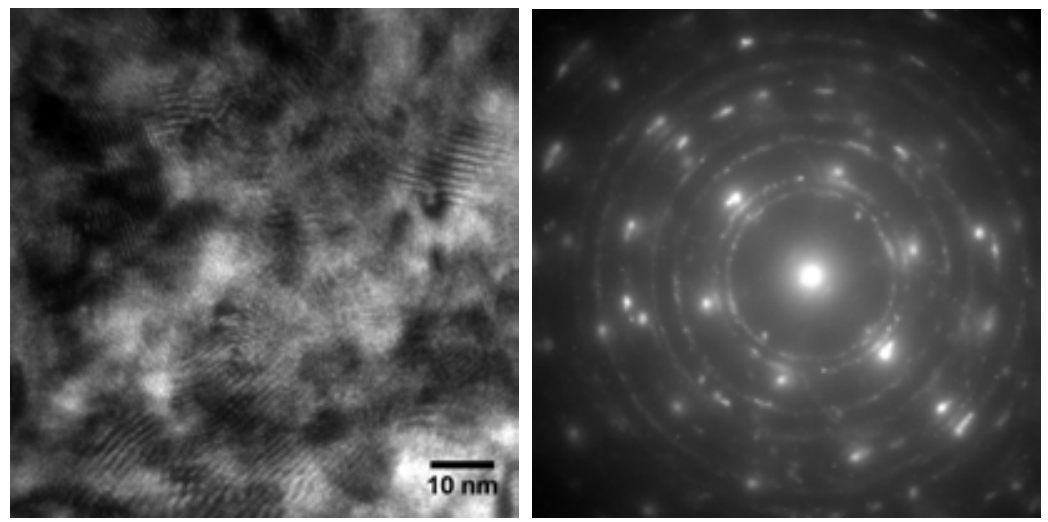

Figure 8. Microstructure of the gauge section of a creep ruptured $\mathrm{Z}$-alloy at $650^{\circ} \mathrm{C}$ and $110 \mathrm{MPa}$. 


\section{THERMAL AGING RESISTANCE AT 600 AND $700^{\circ} \mathrm{C}$}

Type SS-3 specimens of T-alloys and Z-alloys were sealed separately in argon back-filled quartz tubes which were aged in box furnaces at 600 and $700^{\circ} \mathrm{C}$. The 600 and $700^{\circ} \mathrm{C}$ thermal aging had achieved 5,906 and 5,236 h, respectively. Tensile tests of the aged specimens were conducted at room temperature and $600^{\circ} \mathrm{C}$. Their tensile properties are compared to the control condition without the aging. Specimens with a longer aging time of $10,200 \mathrm{~h}$ at 600 and $700^{\circ} \mathrm{C}$ have been completed recently. Their tensile test was delayed because of the problems of the tensile test system.

Figure 9 shows the changes of yield strength, tensile strength, and total elongation at room temperature of the aged specimens as compared to the control specimens. The T-alloys exhibited softening with reduced yield/tensile strength and increased total elongation after the aging at 600 and $700^{\circ} \mathrm{C}$. The higher aging temperature resulted in greater softening. Alloy TTZ1 with a small amount of $\mathrm{Zr}$ alloying into alloy TT1 led to reduction in the softening at both 600 and $700^{\circ} \mathrm{C}$. In contrast, the Z-alloy (Z6) showed some $(\sim 10 \%)$ hardening after the aging at both 600 and $700^{\circ} \mathrm{C}$. The aging temperatures did not result in noticeable difference in the hardening. However, the higher aging temperature $\left(700^{\circ} \mathrm{C}\right)$ tended to have hardening without impairing total elongation. The longer time aging $(10,200 \mathrm{~h})$ as well as additional T-alloys and Z-alloys will help confirm the trend of the thermal aging effect on the two types of alloys.
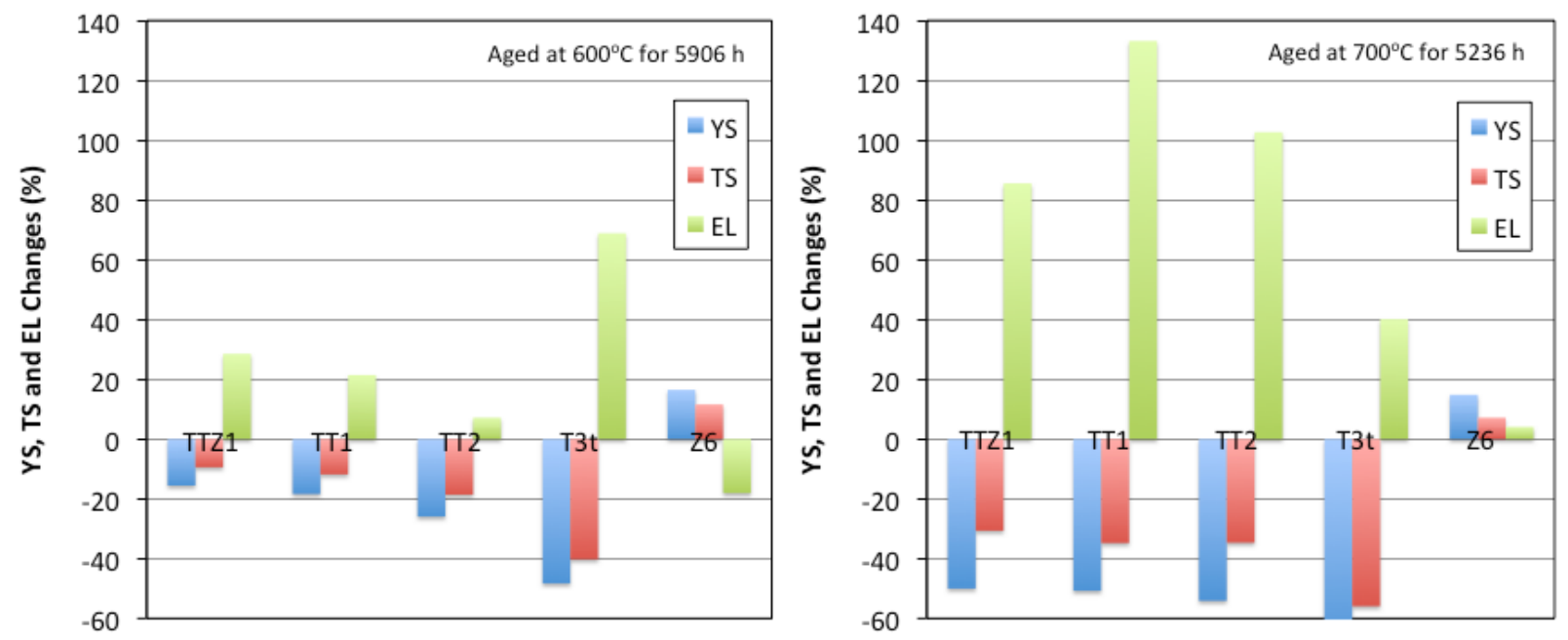

Figure 9. Changes of yield strength (YS), tensile strength (TS), and total elongation (EL) at room temperature of the T-alloys and $\mathrm{Z}$-alloys after aging at 600 and $700^{\circ} \mathrm{C}$ for 5,906 and $5,236 \mathrm{~h}$, respectively. 


\section{CHARPY V-NOTCH IMPACT TOUGHNESS}

Charpy impact resistance is an important property of ferritic steels, which influences the application condition of the materials. Charpy impact tests were conducted on a Tinius Olsen Charpy $300 \mathrm{ft}-\mathrm{lb}$ machine according to ASTM Standard E23-12c, Standard Test Methods for Notched Bar Impact Testing of Metallic Materials. The measurement calibration of the Charpy machine is performed annually through testing of specimens with certified values to verify the accuracy of the machine. The certified specimens are obtained from the National Institute of Standards and Technology (NIST). Half-size Charpy V-notch specimens with a specification shown in Figure 10 were used to screen the absorbed impact energies at temperatures ranging from $-150^{\circ} \mathrm{C}$ to $300^{\circ} \mathrm{C}$ to determine ductile-brittle transition temperature (DBTT) and upper-shelf energy (USE) of the developed alloys. The specimens were primarily tested in the T-L (transverse-longitudinal) orientation with V-notch aligned with the longitudinal direction because this orientation usually gives the worst impact toughness as compared to the other specimen orientations, e.g., the L-T orientation with V-notch aligned with the transverse direction.

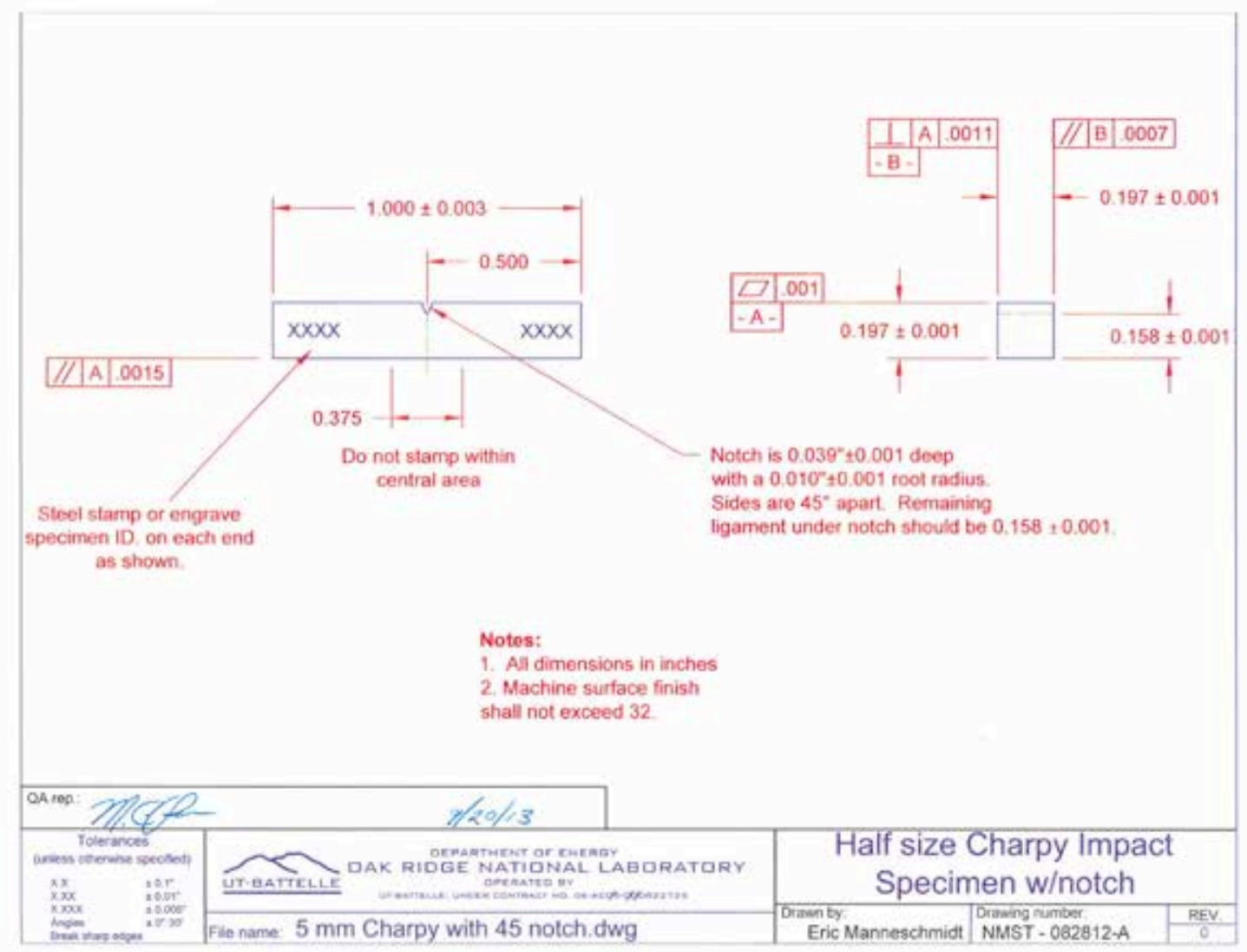

Figure 10. Specification of half-size Charpy V-notch specimen.

The tested results of two T-alloys are plotted in Figure 11. The literature data of Grade 91 using the same type of half-size Charpy V-notch specimens in the same T-L orientation are included for comparison [12]. To obtain DBTT and USE, impact energy-temperature curves were generated by fitting the data with a hyperbolic tangent function $E=a+b \tanh \left[\left(T-T_{0}\right) / c\right]$, where $T$ is test temperature and $a$, $b, c$ and $T_{0}$ are regression coefficients. In this study, $T_{0}$ is the mathematical DBTT, corresponding to the 
mean value of USE and lower-shelf energy (LSE), i.e., 1/2USE assuming LSE $=0$ in this study. In comparison, engineering DBTT is determined at $6.5 \mathrm{~J}$ for the half-size specimen $(5 \times 5 \times 25 \mathrm{~mm})$, lower than the $41 \mathrm{~J}$ criterion for full-size specimen $(10 \times 10 \times 55 \mathrm{~mm})$ [13]. The analyzed results of the two T-alloys and Grade 91 are summarized in Table 2. As compared to Grade 91, the T-alloys have about $25^{\circ} \mathrm{C}$ lower DBTT in terms of the mathematic DBTT at $1 / 2 \mathrm{USE}$ and about $12^{\circ} \mathrm{C}$ lower DBTT in terms of the engineering DBTT at $6.5 \mathrm{~J}$. In the meantime, the USE of the T-alloys is about double that of the Grade 91, which suggested significant improvement in Charpy impact toughness of the T-alloys. The general USE of 12-14Cr oxide-dispersion-strengthened (ODS) or nano-structured ferritic alloys (NFA) in the same type of Charpy $\mathrm{V}$-notch specimen is only about $5 \mathrm{~J}$ as shown with dashed horizontal line in Figure 11. A few Z-alloy half-size Charpy V-notch specimens tested at room temperature exhibited USE comparable to or lower than the ODS/NFA. Active developmental activities are in progress to improve the toughness of the intermetallic-strengthened ferritic alloys (Z-alloys).

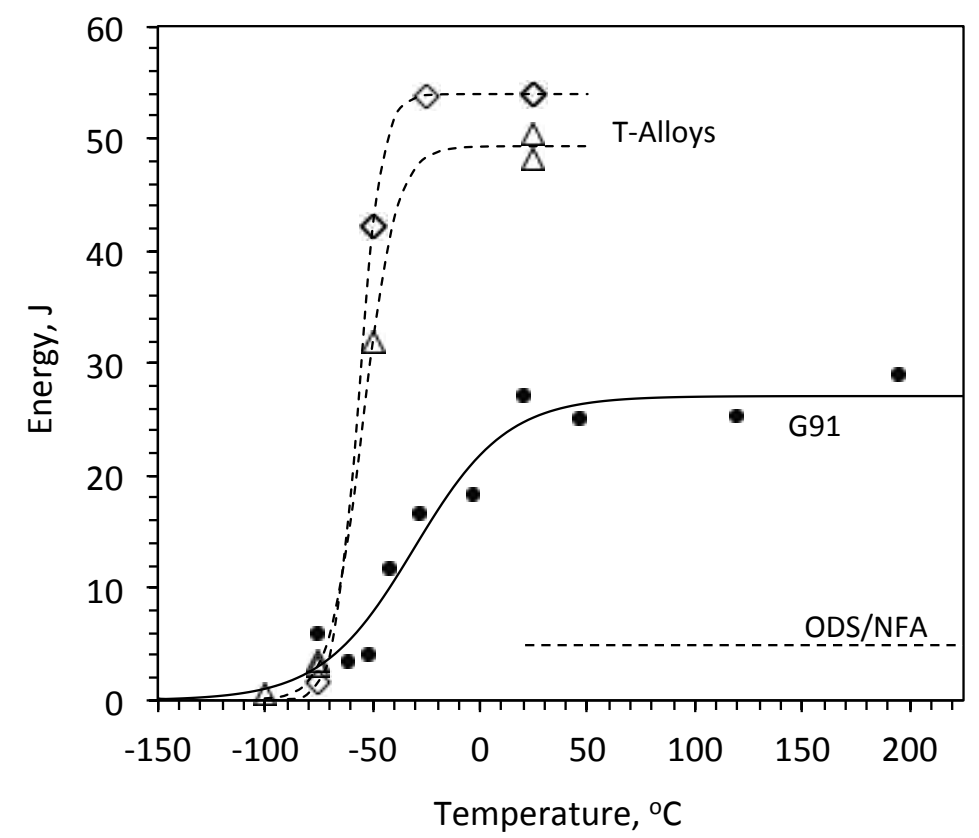

Figure 11. Charpy V-notch impact tested data and fitted curves of T-alloys in the T-L orientation as compared with Grade 91.

Table 2. DBTT and USE of the T-alloys and Grade 91.

\begin{tabular}{cccc}
\hline Alloy & Mathematic DBTT & Engineering DBTT & USE \\
\cline { 2 - 4 } Sample & $(1 / 2 \mathrm{USE}),{ }^{\circ} \mathrm{C}$ & $(6.5 \mathrm{~J}),{ }^{\circ} \mathrm{C}$ & $\mathrm{J}$ \\
\hline T-alloys & -56.7 & -67.1 & 54.0 \\
& -54.6 & -69.1 & 49.3 \\
Grade 91 & -30.7 & -55.5 & 27.1 \\
\hline
\end{tabular}




\section{NICKEL-CONTAINING Z-ALLOYS}

\subsection{THERMODYNAMIC MODELING OF FE-CR-ZR-NI SYSTEM}

The $\mathrm{Fe}_{2} \mathrm{Zr}$ Laves phase has dihexagonal $\mathrm{C} 36$ structure at high temperature and cubic $\mathrm{C} 15$ structure at low temperature. When $\mathrm{Cr}$ is added, the hexagonal $\mathrm{C} 14$ structure can also be stabilized. These polytypes are related to each other because the basic unit layer of these phases is the same, while the stacking sequence of the unit layer is different in each structure. Despite the excellent high-temperature strength of the Laves phases, the low ductility and brittle fracture characteristics at ambient temperature are the main limitations for structural applications. The high hardness and brittle fracture of Laves phase are due to the complex atomic configuration of each unit layer, interplanar locking, and lack of operating slip systems at ambient temperature. In view of this problem, the dual-phase alloying concept based on a soft solid solution matrix reinforced with hard Laves phase particles has been proposed for practical alloy development, as employed in this study. New Fe-Cr-Zr ferritic alloys with the C14 Laves phase as the strengthening component have been developed. These new alloys show one order of magnitude higher enhancement on high-temperature tensile and creep strength over conventional P91 ferritic/martensitic steels. Despite the success in high-temperature mechanical properties, these alloys suffer from the low fracture toughness at ambient temperature. Thermodynamic modeling and experimental investigation identified the hexagonal $\mathrm{C} 14$ structure as the prevalent structure in $\mathrm{Fe}-\mathrm{Cr}-\mathrm{Zr}$ alloys. The literature review suggested that the fracture toughness of $\mathrm{C} 14$ structure is lower than that of $\mathrm{C} 15$ structure, which was attributed to the fact that the cubic $\mathrm{C} 15$ structure has more operating slip system, therefore is more deformable than the hexagonal $\mathrm{C} 14$ structure. Following this concept, Ni was proposed to be added into the current $\mathrm{Fe}-\mathrm{Cr}-\mathrm{Zr}$ alloy, with the goal to convert the hexagonal $(\mathrm{Fe}, \mathrm{Cr})_{2} \mathrm{Zr}$ _C14 Laves phase into the cubic $(\mathrm{Fe}, \mathrm{Cr}, \mathrm{Ni})_{2} \mathrm{Zr} \_\mathrm{C} 15$ structure.
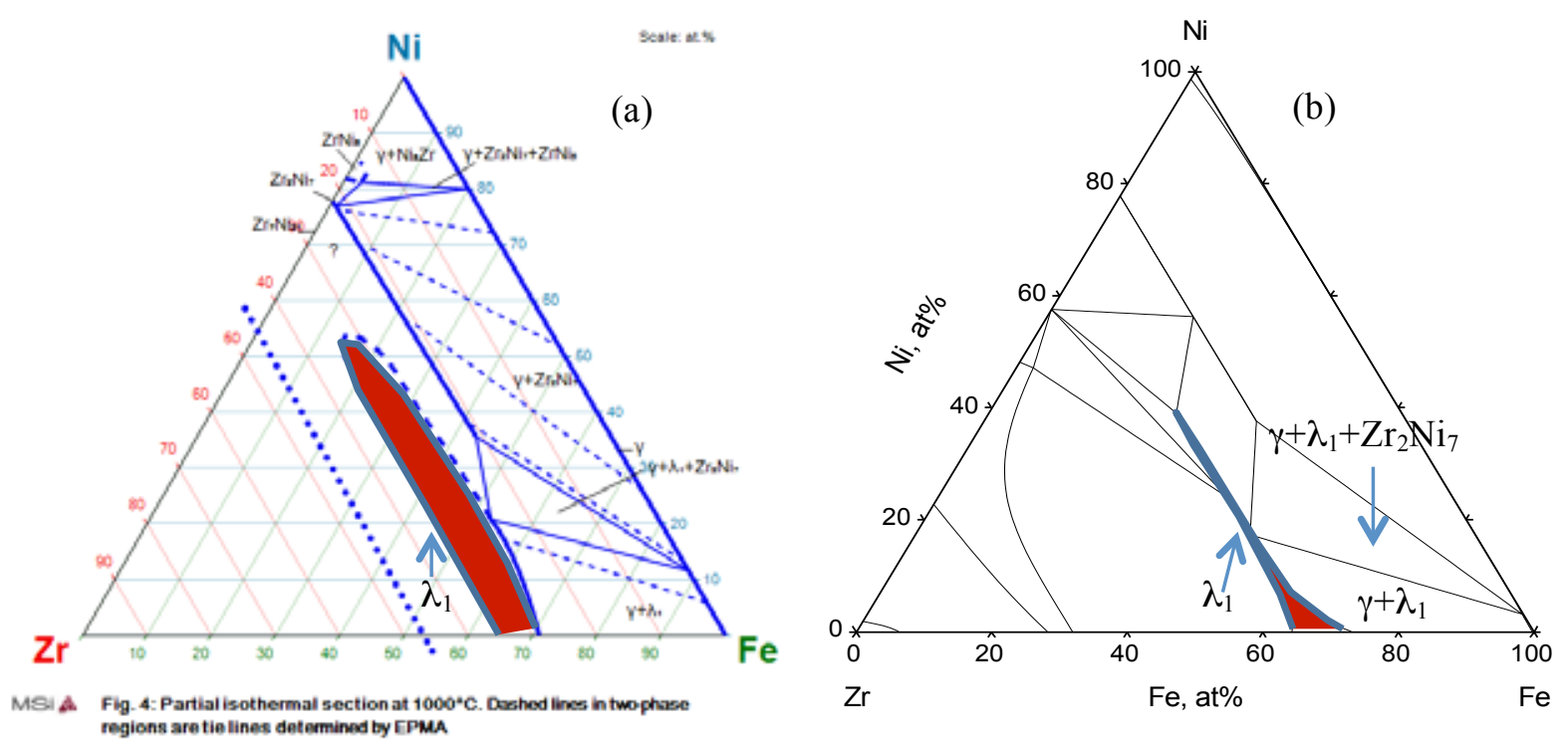

Figure 12. Partial isothermal section of $\mathrm{Fe}-\mathrm{Ni}-\mathrm{Zr}$ at $1, \mathbf{0 0 0}^{\circ} \mathrm{C}$ : (a) experimental, (b) calculated.

The partial isothermal section of $\mathrm{Fe}-\mathrm{Ni}-\mathrm{Zr}$ at $1,000^{\circ} \mathrm{C}$ is shown in Figure $12 \mathrm{a}$, in which the $\lambda 1$ phase is the $(\mathrm{Fe}, \mathrm{Ni})_{2} \mathrm{Zr} \_\mathrm{C} 15$ phase. Clearly, Ni stabilizes the $\mathrm{C} 15$ structure. The solubility of $\mathrm{Ni}$ in $\mathrm{Fe}_{2} \mathrm{Zr} \mathrm{C}_{-} 15$ phase can be up to 20 at. $\%$ for the $\mathrm{Bcc}(\mathrm{Fe}, \mathrm{Cr})+\mathrm{Fe}_{2} \mathrm{Zr}$ _C15 two-phase region. A preliminary thermodynamic model on $(\mathrm{Fe}, \mathrm{Ni})_{2} \mathrm{Zr}$ _C15 Laves phase has been developed in this study. The calculated 
partial isothermal section is shown in Figure 12b. The region relevant to this study is the $\gamma+\lambda_{1}$ and $\gamma+\lambda_{1}+\mathrm{Zr}_{2} \mathrm{Ni}_{7}$ phase equilibria.

\subsection{STABILITY OF THE LAVES PHASE}

By incorporating the newly developed thermodynamic model of (Fe,Ni) ${ }_{2} \mathrm{Zr}$ C15_Laves phase into the OCTANT (Ornl Computational Thermodynamics for Nuclear Technology) thermodynamic database, the stability of relevant phases in Fe-Cr-Ni-Zr alloys can be calculated. Although the thermodynamic description for the $\mathrm{Fe}-\mathrm{Cr}-\mathrm{Ni}-\mathrm{Zr}$ quaternary system is still preliminary due to the lack of experimental validation, it provides important trend analysis of the $\mathrm{Ni}$ effect on the stability of the Laves phases in the $\mathrm{Fe}-\mathrm{Cr}-\mathrm{Zr}$ alloys. Based on thermodynamic calculation results, three $\mathrm{Fe}-\mathrm{Cr}-\mathrm{Zr}$ alloys with different $\mathrm{Ni}$ concentrations were designed for experimental study. They are Fe-12Cr-6Zr base alloys with addition of $0.5,2$ and $4 \mathrm{wt} \% \mathrm{Ni}$, respectively. The detailed compositions of the alloys are not presented here due to potential proprietary concerns. The amount of Laves phase in $\mathrm{C} 14$ and $\mathrm{C} 15$ structures in these alloys is plotted as a function of temperature in Figure 13. At $0.5 \mathrm{wt} \% \mathrm{Ni}$, the hexagonal $\mathrm{C} 14$ phase is the major one, plotted as the solid black line. It forms from liquid through the eutectic reaction of Liquid $\rightarrow \mathrm{Bcc}(\mathrm{Fe}, \mathrm{Cr})+\mathrm{Fe}_{2} \mathrm{Zr} \mathrm{C} 14$. The $\mathrm{C} 14$ Laves phase is decomposed into the $\mathrm{C} 15$ structure at temperatures below $900^{\circ} \mathrm{C}$ (the sold red line). The formation of C14 and $\mathrm{C} 15$ Laves phase in the alloy with $0.5 \mathrm{wt} \% \mathrm{Ni}$ is similar to that in Fe-Cr-Zr alloys without $\mathrm{Ni}$ addition. At $2 \mathrm{wt} \% \mathrm{Ni}$, the $\mathrm{C} 15$ phase is the primary Laves phase formed from the eutectic reaction Liquid $\rightarrow \mathrm{Bcc}\left(\mathrm{Fe}, \mathrm{Cr}\right.$ ) $+\mathrm{Fe}_{2} \mathrm{Zr} \_\mathrm{C} 15$ (the red dashed line), suggesting that the increasing Ni concentration greatly stabilizes the $\mathrm{C} 15$ structure. The $\mathrm{C} 14$ structure is now the secondary phase formed at low temperature. With further addition of $\mathrm{Ni}, 4 \mathrm{wt} \%$, there is no dramatic change in terms of phase stability and amounts.

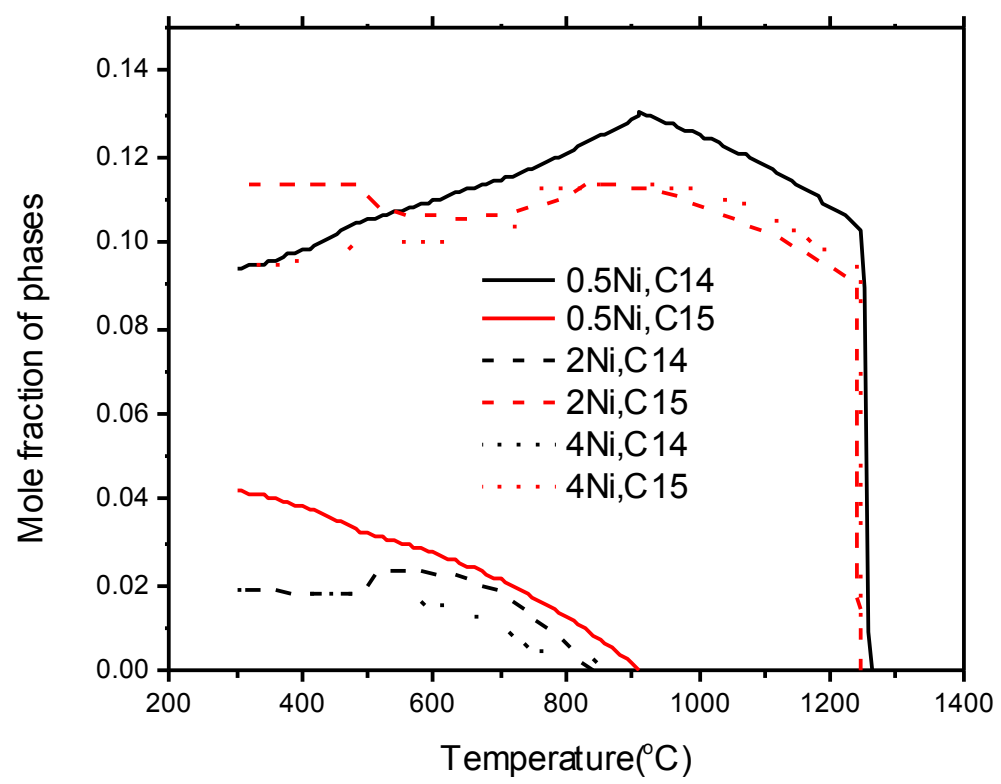

Figure 13. The mole fraction of the C14 and C15 Laves phase vs. temperature in the Fe-12Cr-6Zr base alloy with different additions of $\mathrm{Ni}$. The solid, dashed and dotted lines denote $0.5,2$ and $4 \mathrm{wt} \% \mathrm{Ni}$, respectively. The black and red colors denote the $\mathrm{C} 14$ and $\mathrm{C} 15$ structure, respectively.

It has been shown that by increasing the $\mathrm{Ni}$ content from 2 to $4 \mathrm{wt} \%$, no additional Laves phase can form. This is because the $\mathrm{C} 15$ structure has a large solubility of Ni. Figure 14 plots the solubility of Ni in the $\mathrm{C} 14$ and $\mathrm{C} 15$ structure as a function of temperature for $0.5,2$ and $4 \mathrm{wt} \% \mathrm{Ni}$ alloys. Again, the solid, 
dashed and dotted lines denote $0.5,2$ and $4 \mathrm{wt} \% \mathrm{Ni}$, respectively. The black and red color denotes the $\mathrm{C} 14$ and $\mathrm{C} 15$ structure, respectively. For the $0.5 \mathrm{wt} \%$ alloy, the dissolved $\mathrm{Ni}$ in both $\mathrm{C} 14$ and $\mathrm{C} 15$ structures is due to the limited $\mathrm{Ni}$ available from the bulk composition. In $2 \mathrm{wt} \%$ alloy, the dissolved $\mathrm{Ni}$ in the $\mathrm{C} 15$ structure is significantly increased, while that in $\mathrm{C} 14$ structure remains at a minimum. When further increasing the $\mathrm{Ni}$ content to $4 \mathrm{wt} \%$, the dissolved $\mathrm{Ni}$ in $\mathrm{C} 15$ structure is continuously rising, while that in the $\mathrm{C} 14$ structure is still at a minimum. The amount of dissolved $\mathrm{Ni}$ in the $\mathrm{C} 15$ structure is determined by the solubility of $\mathrm{Ni}$ in this structure. As shown in the isothermal section of $\mathrm{Fe}-\mathrm{Ni}-\mathrm{Zr}$ at $1,000^{\circ} \mathrm{C}$, the solubility of $\mathrm{Ni}$ in $\mathrm{Fe}_{2} \mathrm{Zr} \_\mathrm{C} 15$ phase can be up to 20 at.\% for the $\mathrm{Bcc}(\mathrm{Fe}, \mathrm{Cr})+\mathrm{Fe}_{2} \mathrm{Zr} \_\mathrm{C} 15$ two-phase region. Therefore, the $\mathrm{Ni}$ behavior in the $(\mathrm{Fe}, \mathrm{Cr})_{2} \mathrm{Zr}$ Laves phase is inherited from the Fe-Ni-Zr ternary

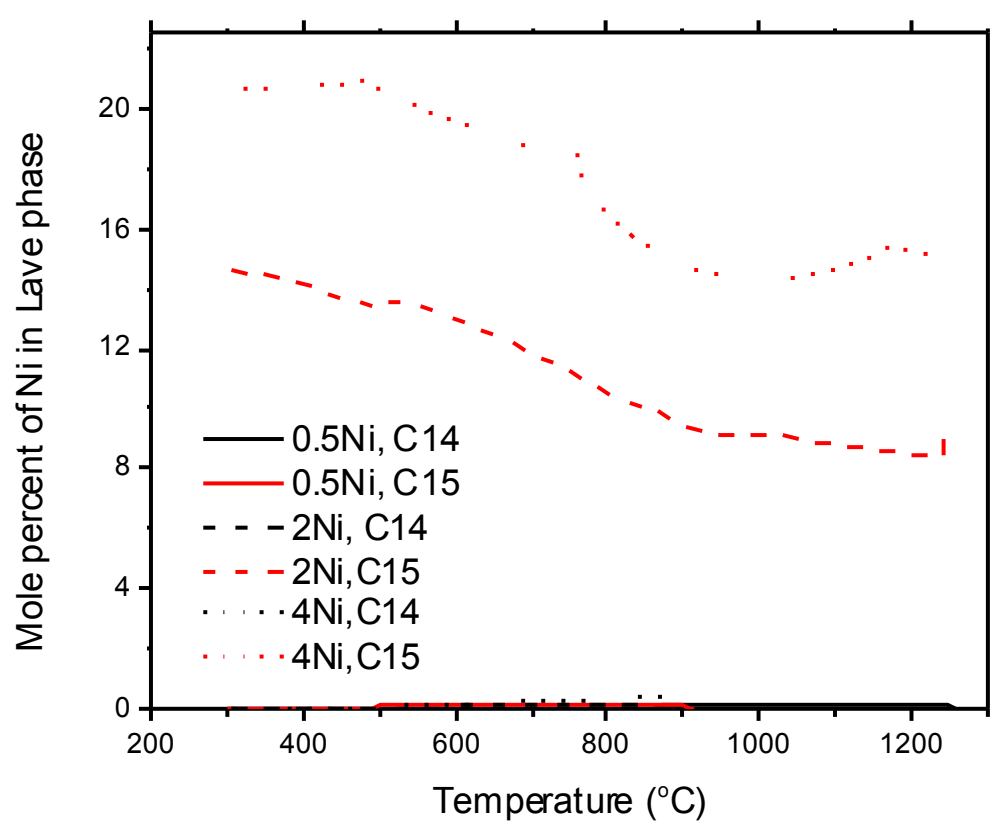

Figure 14. The dissolved $\mathrm{Ni}$ in the $\mathrm{C} 14$ and $\mathrm{C} 15$ Laves phase vs. temperature in the $\mathrm{Fe}-12 \mathrm{Cr}-6 \mathrm{Zr}$ base alloy with different additions of $\mathrm{Ni}$. The solid, dashed and dotted lines denote $0.5,2$ and $4 \mathrm{wt} \% \mathrm{Ni}$, respectively. The black and red colors denote the $\mathrm{C} 14$ and $\mathrm{C} 15$ structure, respectively.

\subsection{MICROSTRUCTURAL CHARACTERIZATION OF NI-CONTAINING ALLOYS}

Scanning electron microscopy (SEM) coupled with energy dispersive x-ray spectroscopy (EDS) and electron-backscattered diffraction (EBSD) was used for morphology, composition, and orientation analyses. SEM/EDS/EBSD was performed using a JEOL JSM 6500F microscope with a field emission gun (FEG), equipped with EDAX EDS and EBSD systems. The accelerating voltage was $20 \mathrm{kV}$, and the working distance was 12 to $17 \mathrm{~mm}$. EBSD maps were measured on a hexagonal grid with a step size of $\leq 0.5 \mu \mathrm{m}$. The camera operated in $2 \times 2$ binning mode at $\sim 100$ frames per second (fps). These parameters were chosen to keep the EBSD analysis time within reasonable limits taking into account the large size of the scanned areas.

Figure $15 \mathrm{a}$ and $\mathrm{b}$ shows the backscattered electronic image (BEI) of the Fe-12Cr-6Zr base alloy with 0.5 and $4 \mathrm{wt} \% \mathrm{Ni}$, respectively. The BEI of the alloy with $2 \mathrm{wt} \% \mathrm{Ni}$ is shown here due to the similarity to these two alloys. The indents in the micrograph of $4 \mathrm{wt} \%$ alloy were caused by hardness measurements, which were also used to align the EBSD scans. Both micrographs consist of the large 
primary ferrite phase surrounded by a network of $\mathrm{Bcc}(\mathrm{Fe}, \mathrm{Cr})+\mathrm{Fe}_{2} \mathrm{Zr}$ eutectic. The phase with the bright white feature is the $\mathrm{Fe}_{2} \mathrm{Zr}$ phase. The grey and dark features are ferrite matrix in slightly different grain orientations. With increasing Ni content from 0.5 to $4 \mathrm{wt} \%$, no significant changes in the amount of primary and eutectic phases have been observed.

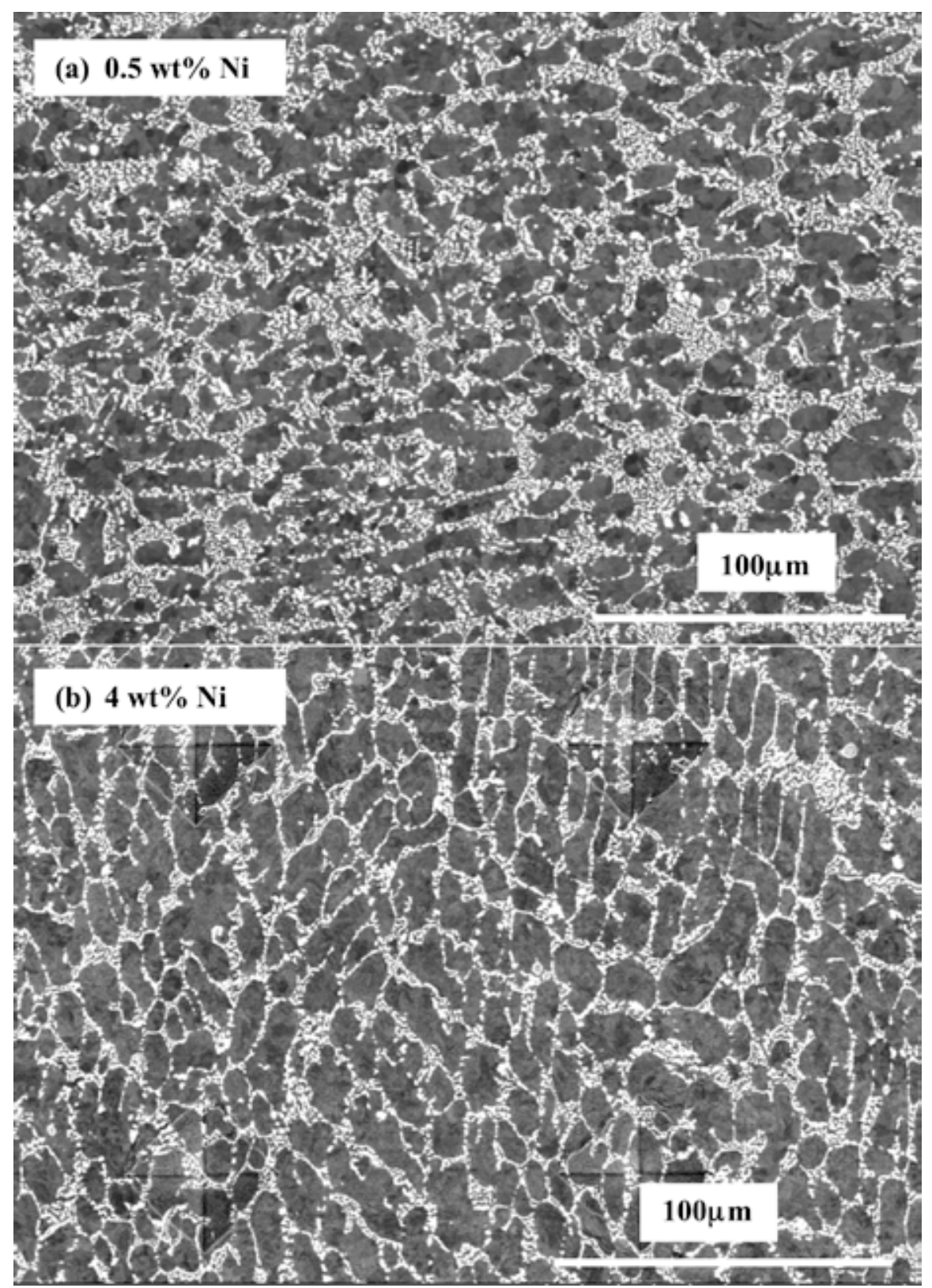

Figure 15. BEIs of Fe-12Cr-6Zr base alloy with additions of (a) 0.5 and (b) 4 wt\% Ni.

The EBSD maps in the forms of image quality (IQ) and inverse pole figure (IPF) for alloys with 0.5 and $4 \mathrm{wt} \% \mathrm{Ni}$ are shown in Figure $16 \mathrm{a}-\mathrm{d}$. The phases of $\mathrm{Bcc}(\mathrm{Fe}), \mathrm{Fe}_{2} \mathrm{Zr} \_\mathrm{C} 14$, and $\mathrm{Fe}_{2} \mathrm{Zr}$ C 15 were used during the EBSD mapping. The IQ maps describe the quality of the collected EBSD patterns, which is strongly affected by the perfection of the crystal lattice in the diffracting volume. Lower IQ corresponds to lower contrast in the IQ images, which is associated with disortions to the crystal lattice. The IQ maps in Figure $16 \mathrm{a}$ and $\mathrm{c}$ indicate that low IQ regions are primarily associated with the Laves phases in the 
eutectic network, as well as the grain and subgrain boundaries. The low IQ of the Laves phase is likely because of its complex crystal structure as compared to the matrix ferritic $\mathrm{Bcc}(\mathrm{Fe})$ phase. The alloy with $4 \mathrm{wt} \% \mathrm{Ni}$ shows a denser eutectic network and more subgrains in the primary/matrix phase than the alloy with $0.5 \mathrm{wt} \% \mathrm{Ni}$. The alloys have been produced by the same processing and yielded greater hardness of the alloy with $4 \mathrm{wt} \% \mathrm{Ni}$ as compared to the alloy with $0.5 \mathrm{wt} \% \mathrm{Ni}(257.5 \pm 2.1$ vs. $210.5 \pm 2.5)$. The IPF maps show the grain orientation of the samples. The pronounced subgrains in the alloys exhibit slight variations in orientation. Laves phase has been primarily identified as $\mathrm{Fe}_{2} \mathrm{Zr}$ Cl14 in the alloys. Despite the observation of some $\mathrm{Fe}_{2} \mathrm{Zr} \mathrm{C} 15$ in the alloy with $4 \mathrm{wt} \% \mathrm{Ni}$, it may have not been well identified at this magnification. Further EBSD characterization at higher magnificantions is currently ongoing to reveal the effect of $\mathrm{Ni}$ content on the presence of $\mathrm{Fe}_{2} \mathrm{Zr} \_\mathrm{C} 15$ Laves phase.
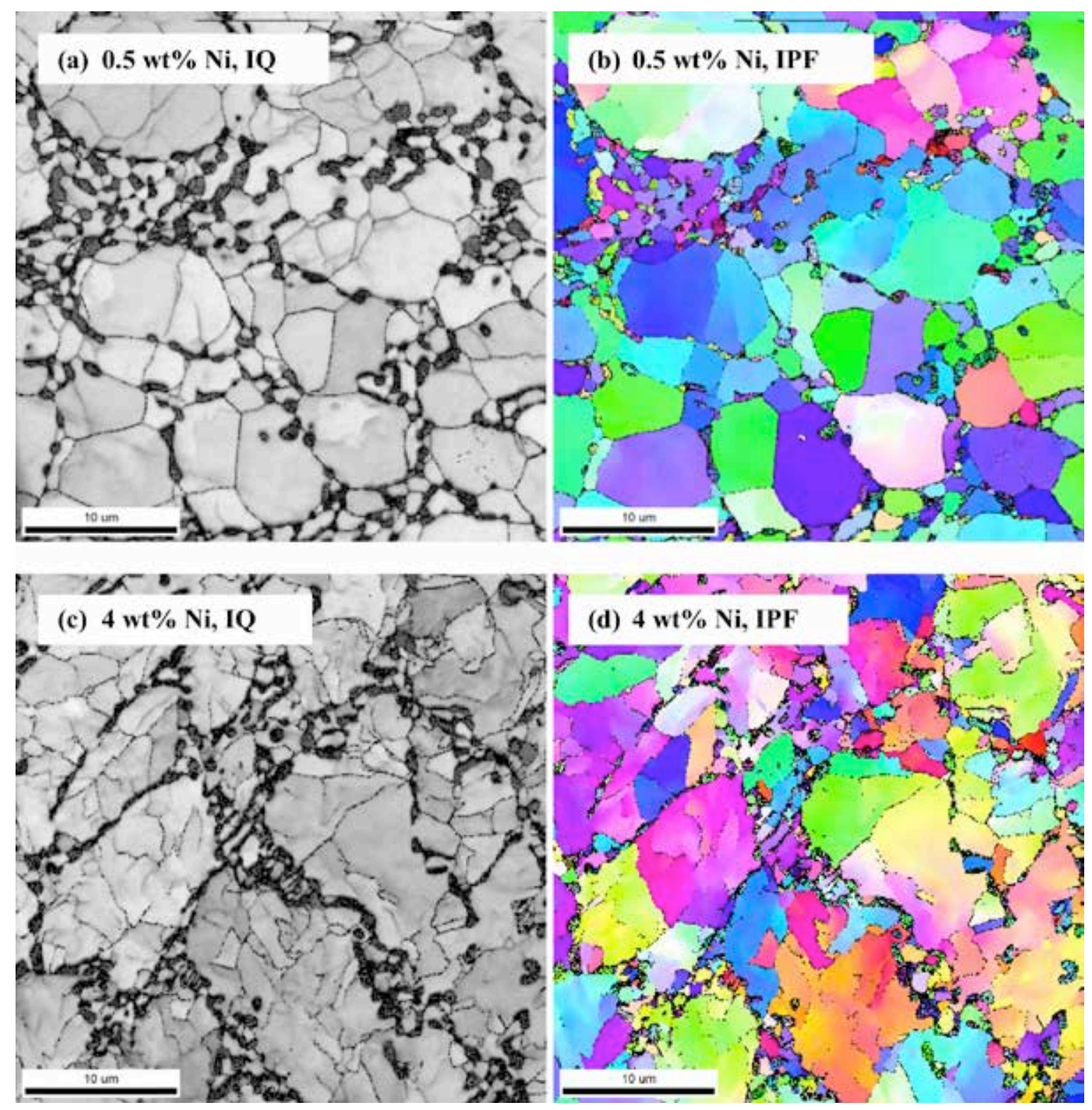

Figure 16. EBSD IQ and IPF maps of Fe-12Cr-6Zr alloys with (a-b) 0.5 and (c-d) 4 wt\% Ni. 
The composition of phases was analyzed by EDS mapping. As shown in Figure 17, the $\mathrm{Fe}_{2} \mathrm{Zr}$ phase in the eutectic zone of the alloy with $0.5 \mathrm{wt} \% \mathrm{Ni}$ has lower Fe and $\mathrm{Cr}$ but enriched $\mathrm{Zr}$ content than the matrix ferrite phase that is enriched with $\mathrm{Fe}$ and $\mathrm{Cr}$. Noticeable Ni enrichment was not observed in this alloy sample, which suggests uniform distribution. For the alloy with $4 \mathrm{wt} \% \mathrm{Ni}$ as shown in Figure 18, enrichment of $\mathrm{Ni}$ is consistent with the $\mathrm{Zr}$ site at the Laves phase. This is in agreement with the thermodynamically calculated solubility of $\mathrm{Ni}$ in the Laves phase in Figure 14. Depletion of $\mathrm{Cr}$ is consistent with $\mathrm{Fe}$ at the Laves phase and is similar to the alloy with $0.5 \mathrm{wt} \% \mathrm{Ni}$.

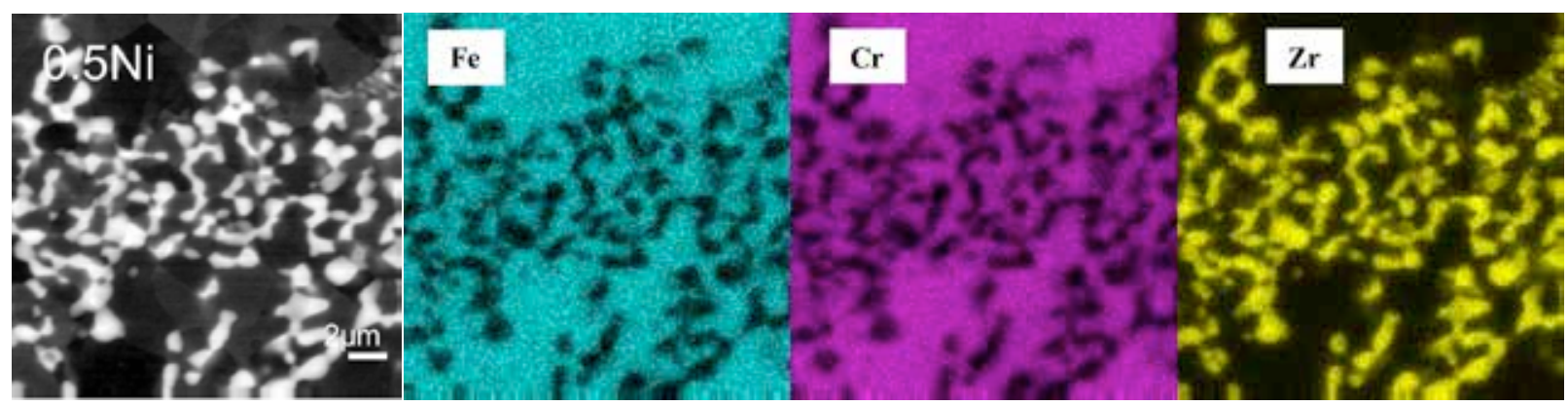

Figure 17. EDS maps of $\mathrm{Fe}, \mathrm{Cr}$ and $\mathrm{Zr}$ in the alloy with $0.5 \mathrm{wt} \% \mathrm{Ni}$.
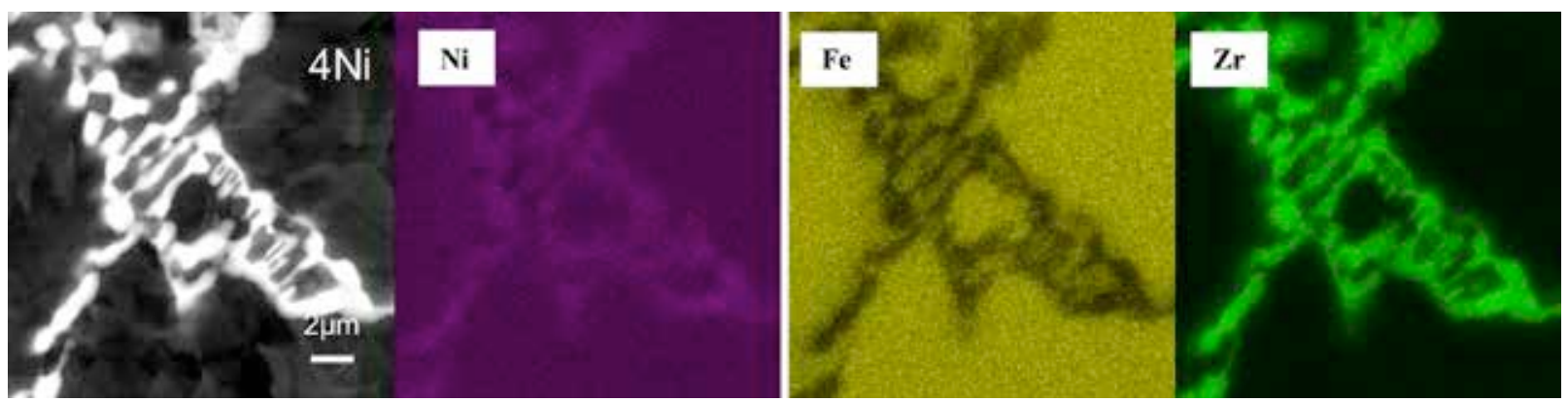

Figure 18. EDS maps of $\mathrm{Ni}, \mathrm{Fe}$, and $\mathrm{Zr}$ in the alloy with $4 \mathrm{wt} \% \mathrm{Ni}$. 


\section{SUMMARY}

The continued development and investigation of the T-alloys and Z-alloys in the third year of this project identified the strengthening mechanisms for the superior yield/tensile strength and creep resistance as compared to P91. The T-alloys exhibited $\sim 300$ to $100 \mathrm{MPa}$ increases in yield/tensile strength from room temperature to $\sim 750^{\circ} \mathrm{C}$. The Z-alloys showed comparable or slightly lower yield strength at temperatures below $\sim 600^{\circ} \mathrm{C}$, above which the Z-alloys exhibited higher yield strength approaching the T-alloys. Microstructural characterization and the modeling of strengthening elements suggest that the notable strength increase of the T-alloys is primarily attributable to the significantly increased amount of ultrafine $\mathrm{MX}(\mathrm{M}=$ metal, $\mathrm{X}=\mathrm{C} / \mathrm{N})$ type nanoprecipitates. In contrast, the $\mathrm{Z}$-alloys are primarily strengthened by the network of eutectic structure. The T-alloys and Z-alloys had increased creep lives by 2 to 4 times the $\mathrm{P} 91$ tested at $650^{\circ} \mathrm{C}$ and $110 \mathrm{MPa}$. The increased amount of MX nanoprecipitates in the T-alloys helped pin the subgrains during creep. Many ultrafine particles $(\sim 10 \mathrm{~nm})$ were randomly formed in the Z-alloys during the creep test, which helped improve creep life without impairing creep ductility.

Thermal aging at 600 and $700^{\circ} \mathrm{C}$ for more than 5,200 h indicated that a small amount of $\mathrm{Zr}$ alloying can mitigate aging-induced softening in the T-alloys. In contrast, the Z-alloys exhibited some aginginduced hardening without noticeable changes to total elongation, which is attributable to new phase precipitation similar to that formed during the creep test. The longer time aging at 600 and $700^{\circ} \mathrm{C}$ for $10,200 \mathrm{~h}$ has been completed. Tensile tests will be conducted to confirm the trend of the thermal aging effect on the T-alloys and Z-alloys. Charpy V-notch impact tests showed the significant improvement in impact toughness of the T-alloys as compared to P91, e.g., $\sim 20^{\circ} \mathrm{C}$ decrease in ductile-brittle transition temperature and about double of the upper-shelf energy of P91. However, the impact toughness of the Z-alloys was significantly lower, which needs to be further investigated and developed. Thermodynamic modeling indicates that nickel alloying into the Z-alloys can favor Laves phase formation in cubic C15 structure rather than the hexagonal C14 structure. The C15-type Laves is believed to have better fracture toughness as well as coherency with ferritic phase as compared to the $\mathrm{C} 14$ type. Preliminary experimental Z-alloys with 0.5 to $4 \mathrm{wt} \% \mathrm{Ni}$ confirmed the significant participation of $\mathrm{Ni}$ in the $\mathrm{Fe}_{2} \mathrm{Zr}$ Laves phase of the alloy with $4 \mathrm{wt} \% \mathrm{Ni}$. Preliminary electron backscattered electron mapping suggested

the presence of some C15 type Laves phase. Detailed microstructural analysis will confirm the formation of the $\mathrm{C} 15$ type $\mathrm{Fe}_{2} \mathrm{Zr}$ Laves phase with Ni participation. 


\section{REFERENCES}

[1] N. Baluc, "On the potentiality of using ferritic/martensitic steels as structural materials for fusion reactors," FT/1-1Rb, International Atomic Energy Agency.

[2] H. Mimura, M. Ohgami, H. Naoi, T. Fujita, "Properties of $9 \mathrm{Cr}-1.8 \mathrm{~W}$ steel with high creep strength for USC boiler piping and tubing applications," in: D. Coutsouradis (Eds.), Materials for Advanced Power Engineering, Kluwer Academic Publishers, The Netherlands, 1994, pp. 361.

[3] B. Raj, M. Vijayalakshmi, "Ferritic steels and advanced ferritic-martensitic steels," in: R.J.M. Konings, T.R. Allen, R.E. Stoller, S. Yamanaka, Comprehensive Nuclear Materials, Elsevier, 2012.

[4] K. Maruyama, K. Sawada, J. Koike, "Strengthening mechanisms of creep resistant tempered martensitic steel," ISIJ International, 41 (2001) 641-653.

[5] L. Tan, T.S. Byun, Y. Katoh, L.L. Snead, "Stability of MX-type strengthening nanoprecipitates in ferritic steels under thermal, stress and ion irradiation," Acta Materialia, 71 (2014) 11-19.

[6] D.G. Morris, M.A. Munoz-Morris, L.M. Requejo, Acta Materialia 54 (2006) 2335-2341.

[7] N. Shigenaka, S. Ono, Y. Isobe, T. Hashimoto, H. Fujimori, S. Uchida, "Effect of zirconium addition to austenitic stainless steels on suppression of radiation induced chromium segregation at grain boundaries under ion irradiation," Journal of Nuclear Science and Technology, 33 (1996) 577581.

[8] M.J. Hackett, J.T. Busby, M.K. Miller, G.S. Was, "Effects of oversized solutes on radiation-induced segregation in austenitic stainless steels," Journal of Nuclear Materials, 389 (2009) 265-278.

[9] L. Tan, Y. Yang, K. Sridharan, B. Tyburska-Püschel, Optimization and Testing Results of Zr-bearing Ferritic Steels, ORNL/TM-2014/440, UT-Battelle, LLC, Oak Ridge National Laboratory, September 2014.

[10] L. Tan, Y. Yang, Progress Report on the Mechanical Testing and Thermal Aging of Zr-bearing Ferritic Steels, ORNL/TM-2013/360, UT-Battelle, LLC, Oak Ridge National Laboratory, September 2013.

[11] L. Tan, J.T. Busby, "Formulating the strength factor $\alpha$ for improved predictability of radiation hardening," Journal of Nuclear Materials, 465 (2015) 724-730.

[12] W.R. Corwin, A.M. Hougland, "Effect of specimen size and material condition on the Charpy impact properties of 9Cr-1Mo-V-Nb steel," in: W.R. Corwin, G.E. Lucas (Eds.), The Use of SmallScale Specimens for Testing Irradiated Material, ASTM STP 888, American Society for Testing and Materials, Philadelphia, 1986, pp. 325-338.

[13] M.A. Sokolov, R.K. Nanstad, "On impact testing of subsize Charpy V-notch type specimens," in: D.S. Gelles, R.K. Nanstad, A.S. Kumar, E.A. Little (Eds.), Effects of Radiation on Materials: $17^{\text {th }}$ International Symposium, ASTM International, STP 1270, 1996, pp. 384. 
